\title{
Oogenesis and egg development in triatomines: a biochemical approach
}

\author{
GEORGIA C. ATELLA ${ }^{1}$, KATIA C. GONDIM ${ }^{1}$, EDNILDO A. MACHADO ${ }^{2}$ \\ MARCELO N. MEDEIROS ${ }^{2}$, MÁRIO A.C. SILVA-NETO ${ }^{1}$ and HATISABURO MASUDA ${ }^{1}$ \\ ${ }^{1}$ Instituto de Bioquímica Médica, Centro de Ciências da Saúde, Bloco H \\ Universidade Federal do Rio de Janeiro, UFRJ, Av. Bauhinia s/n, Cidade Universitária, Ilha do Fundão \\ 21944-590 Rio de Janeiro, RJ, Brasil \\ ${ }^{2}$ Instituto de Biofísica Carlos Chagas Filho, Centro de Ciências da Saúde, Bloco G \\ Universidade Federal do Rio de Janeiro, UFRJ, Av. Bauhinia s/n, Cidade Universitária, Ilha do Fundão \\ 21944-590 Rio de Janeiro, RJ, Brasil \\ Manuscript received on March 3, 2005; accepted for publication on March 30, 2005; \\ presented by Lucia Mendonça Previato
}

\begin{abstract}
In triatomines, as well as in other insects, accumulation of yolk is a process in which an extra-ovarian tissue, the fat body, produces yolk proteins that are packed in the egg. The main protein, synthesized by the fat body, which is accumulated inside the oocyte, is vitellogenin. This process is also known as vitellogenesis. There are growing evidences in triatomines that besides fat body the ovary also produces yolk proteins. The way these yolk proteins enter the oocyte will be discussed. Yolk is a complex material composed of proteins, lipids, carbohydrates and other minor components which are packed inside the oocyte in an organized manner. Fertilization triggers embryogenesis, a process where an embryo will develop. During embryogenesis the yolk will be used for the construction of a new individual, the first instar nymph. The challenge for the next decade is to understand how and where these egg proteins are used up together with their non-protein components, in pace with the genetic program of the embryo, which enables cell differentiation (early phase of embryogenesis) and embryo differentiation (late phase) inside the egg.
\end{abstract}

Key words: oogenesis, vitellogenesis, embryogenesis, triatomines, Rhodnius prolixus.

\section{INTRODUCTION}

During the evolution of species a very important achievement, by Mother Nature, was the development of multicellular organisms starting from a unique cell, the fertilized oocyte. This strategy was adopted by most multicellular organisms and among them we can recognize oviparous and non-oviparous

Dedicated to the memory of Prof. Dr. Herman Lent by initiative of Pedro L. Oliveira, Instituto de Bioquímica Médica. Universidade Federal do Rio de Janeiro (UFRJ), RJ, Brasil. Correspondence to: Hatisaburo Masuda

E-mail: masuda@bioqmed.ufrj.br living organisms. In oviparous organisms, including insects, embryonic development occurs apart from the maternal body. Therefore, egg survival relies on the utilization of previously stored material for embryo's growth. This material, the yolk, is composed of proteins, lipids, sugars and other minor components, and is stored in a highly organized manner inside the egg. Following fertilization the egg will give rise to an entire new organism. During development, yolk will be gradually used in accordance with the needs of specific cells imposed by the genetic program of the embryo. 
The accumulation of yolk, or vitellogenesis, is a process in which extra-ovarian tissues produce yolk protein precursors such as vitellogenin (VG) the principal protein of the oocyte (Postlethwait and Giorgi 1985, Raikhel and Dhadiala 1992). Due to the heterosynthetic nature of vitellogenesis in insects, their oocytes are specialized for the specific accumulation of yolk proteins. Therefore, insect oocytes present a whole set of structures designed to select, internalize and store specific proteins, such as microvilli, coated pits, coated vesicles and yolk granules. In most insects, a single phospholipoglycoprotein, now named Vitellin (VT) to differentiate it from VG, is the main component of the eggs and serves both for embryonic and, in some cases, early larval development (Postlethwait and Giorgi 1985, Zhu et al. 1986, Oliveira et al. 1989).

Triatomines were the first group of insects where the accumulation of an extra-ovarian protein by vitellogenic oocytes was reported. The paper of Sir V.B. Wigglesworth in 1943 described the presence in the egg of Rhodnius prolixus of a pink pigment that was originated from a hemolymphatic precursor. The pigment was thought to be partially degraded hemoglobin "katahemoglobin". The pigment described by Wigglesworth was isolated fifty two years later, and characterized as RHBP (Rhodnius Heme-Binding Protein) in our laboratory (Oliveira et al. 1995), a protein that functions as an antioxidant while in the hemolymph (Dansa-Petretski et al. 1995) and which is accumulated inside the oocytes (Machado et al. 1998). The remarkable paper of Wigglesworth was, in fact, the very first report on the accumulation of an extra-ovarian protein by vitellogenic oocytes, opening the trail that led to the characterization of VG uptake by Telfer (1954). William Telfer (1960) was the first person to associate endocytosis with yolk deposition in oocytes of Hyalophora cecropia. He reported a selective concentration of hemolymph-borne proteins and, in 1961 , the route of entry in yolk granules. Soon after, Roth and Porter (1964) and Roth et al. (1976) observed, in oocytes of the mosquito Aedes aegypti, the presence of coated vesicles, the cellular struc- tures associated with selective endocytosis. These were the pioneering reports that were followed by an enormous amount of other reports that corroborated the initial investigations, as reviewed by Telfer et al. (1982), Raikhel and Dhadiala (1992), and Snigirevskaya and Raikhel (2004). These studies led to major milestones in our understanding of how macromolecules are taken up from surrounding extracellular fluids into both mammalian and insect cells.

The adaptation for blood feeding behavior, among arthropods, evolved independently in several groups so, during the course of evolution, different metabolic adaptations were used to obtain, digest and use this special source of food (Lehane 1991). The majority of blood-feeding insects, including triatomines, ingest a large amount of blood in a single meal, comprising several times the animal's own weight (Friend et al. 1965). The digestion of blood brings to the insect a special problem related to the release of an enormous amount of free heme upon degradation of hemoglobin. Heme is a toxic molecule due to its ability to generate reactive oxygen species (Aft and Mueller 1983, Vincent et al. 1988, Vincent 1989, Smith 1990). Thus, heme toxicity must be counteracted with very efficient defense systems. In $R$. prolixus, several lines of defense have been characterized such as Rhodnius Heme-Binding Protein (RHBP) (Dansa-Petretski et al. 1995); uric acid (Souza et al. 1997); hemozoin formation in the midgut (Oliveira et al. 1999); and antioxidant enzymes (Paes and Oliveira 1999, Paes et al. 2001).

The digested blood, on the other hand, also contains a large amount of amino acids and lipids that can be used to produce molecules such as Vitellogenins (VGs) that are secreted to the hemolymph to be taken up by the growing oocytes. The major hemolymph lipoprotein of insects is called lipophorin, and its most studied role is the inter organ transport of lipids (Chino et al. 1977, 1981), thus lipids can be carried and delivered to the ovaries (Kawooya et al. 1988). Lipophorin is also stored inside the oocytes of moths (Telfer et al. 1991).

Besides proteins, carbohydrates and lipids, the 
A

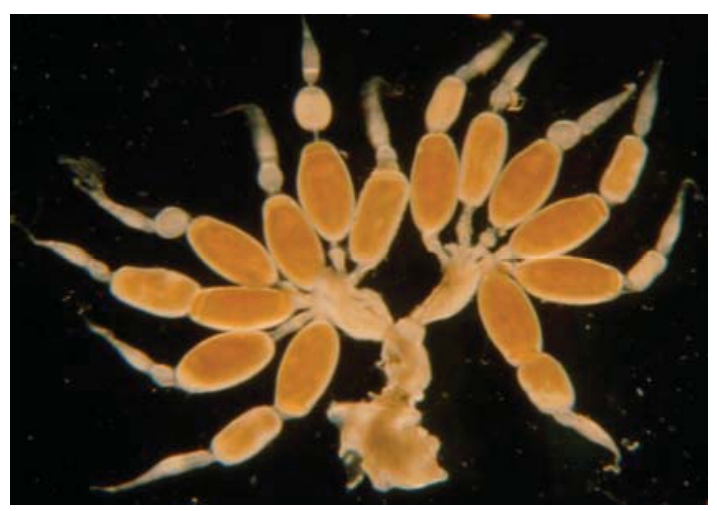

B

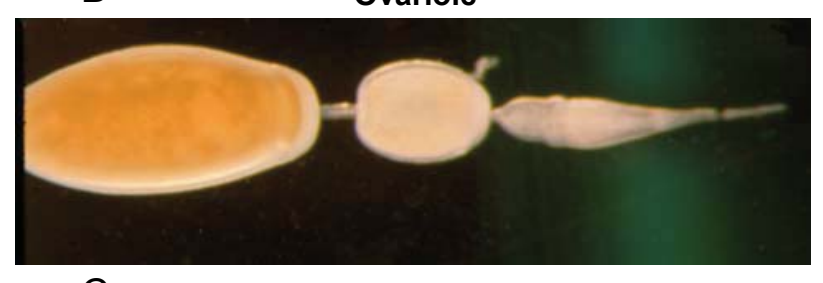

C

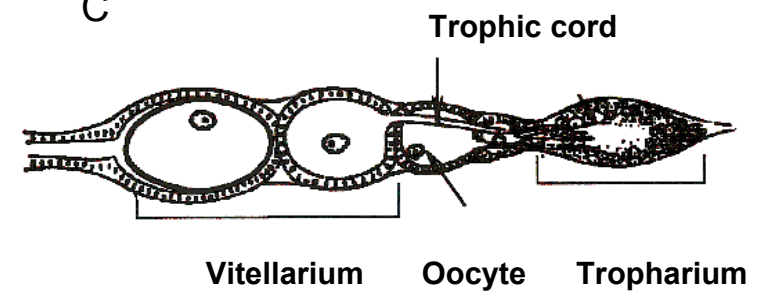

Fig. 1 - The ovary of Rhodnius prolixus: The ovary was dissected at day 5 after blood meal and spread onto a glass slide and photographed. The ovary (A) is composed of two hemi-ovaries that are connected by a common oviduct. Each hemi-ovary is composed of seven structures named ovariole. From the hemi-ovary depicted at the right side of Fig. 1A one ovariole was removed to be shown in detail (B). A line drawing of the ovariole is shown in (C), in order to represent the internal structures (After Huebner and Anderson 1972).

oocytes of triatomines need other components such as heme, calcium, and also mechanical protection of the egg and protection against microorganisms, since embryo development occurs outside maternal body. Once fertilized, the egg is laid and the embryo development is initiated. So, components necessary for embryo development such as DNA, proteins, lipids, carbohydrates and enzymes must all be packed inside the egg.

\section{THE OVARIES OF TRIATOMINES}

A broad spectrum of studies with hemipterans, including triatomines, has established that they are telotrophic (Bonhag 1955, 1958, Davis 1956, Masner 1968, Brunt 1971, Huebner and Anderson 1972, Schreiner 1977, Couchman and King 1979, Buning 1981). Telotrophic ovary is a quite complex structure; as shown in Fig. 1A R. prolixus ovary is composed of two hemi-ovaries. Each hemi-ovary is composed of seven structures named ovarioles which are depicted in Fig. 1B. Internal structures of the ovariole are depicted in Fig. 1C. The cell biology and structures of telotrophic ovaries were reviewed by Telfer et al. (1982) and Huebner (1984). A female of $R$. prolixus is able to produce around
40 to 42 eggs in 15 days after a single blood meal, thus each ovariole is able to produce approximately three eggs, since Rhodnius ovary contains 14 ovarioles. The way these eggs are produced will be commented here. The purpose of this review is to bring into discussion the oocyte proteins of triatomines, especially because these insects feed on blood and use them as substrates to build up their eggs. We present a brief survey of the main proteins and try to describe their mode of entry, their accumulation inside the oocyte and their use by the growing embryo. Among the proteins that will be commented are VGs, lipophorin, Rhodnius Heme-binding protein (RHBP) and Rhodnius Calcium-binding Protein (RCBP). The involvement of enzymes such as phosphatases, proteases and kinases in the mobilization of yolk, during embryogenesis, will also be commented.

\section{VITELLINS AND VITELLOGENINS}

VT is derived from VG, which in most insects is synthesized in the fat body (Pan et al. 1969, Engelmann 1979, Harnish et al. 1982) as a single or multiple precursors that are processed before secretion to the hemolymph (Raikhel et al. 1990, Tufail et al. 2004). 
Synthesis and accumulation of yolk proteins are under hormonal control as reviewed by Hagedorn and Kunkel (1979), Davey (1981), Engelmann (1990), Raikhel and Dhadiala (1992) and Bellés (2004). In some insects, complementary synthesis of VGs by the ovaries has been described (Postlethwait et al. 1980, Bianchi et al. 1985, Rousset et al. 1988, Melo et al. 2000). VG expression and secretion to the hemolymph by fat body and uptake by the ovary are regulated at the hormonal and sexual levels. Since the first report on $R$. prolixus, involving corpus allatum (juvenile hormone) in the regulation of vitellogenesis (Wigglesworth 1936), it has become apparent that juvenile hormone influences vitellogenesis in the majority of insects (Brookes 1969, Engelmann 1970). The replacement of juvenile hormone following the removal of corpora allata restores vitellogenesis.

Among hemipterans, the process of vitellogenesis is, in fact, controlled by juvenile hormone as demonstrated by Coles (1965) in R. prolixus, and by Mundall and Engelmann (1977) in Triatoma protracta. On the other hand, it was also demonstrated in $R$. prolixus that oogenesis is inhibited by ecdysone in a dose-dependent fashion (Garcia et al. 1979). In Triatoma protracta and $R$. prolixus, vitellogenesis is stimulated by mating. The effect of mating on egg production of $R$. prolixus is such that during the early gonadotrophic cycle the rate of vitellogenesis is the same in both mated and virgin females, but at some point onward vitellogenesis is strongly inhibited (Pratt and Davey 1972a). Mating activates corpus allatum to produce juvenile hormone through ventral nervous cord (Mundall and Engelmann 1977, Davey 1987). It is generally accepted that in R. prolixus oogenesis is controlled by hormones, being released in response to abdominal stretch during blood feeding (Davey 1987). Besides that, it was suggested that stretching alone is not enough to induce oogenesis, which is also dependent on the presence of proteins in the diet (Garcia and Azambuja 1985). Insects fed with protein-free diet failed to induce oogenesis although abdominal stretch had occurred. It was also observed that the origin of the blood has strong influence on R. prolixus oogenesis (Lima Gomes et al. 1990, Valle et al. 1987, 1992).

In $R$. prolixus, juvenile hormone acts directly on the ovary, controlling the enlargement of interfollicular channels, a condition known as patency, allowing macromolecules from the hemolymph, such as VG, lipophorin, RHBP etc to reach the surface of the oocyte. This enlargement is thought to be the consequence of $\mathrm{Na}^{+} / \mathrm{K}^{+}$ATPase activity present in follicular cells. This effect is antagonized by antigonadotropins (Pratt and Davey 1972b, Davey 1981). It has been suggested that the function of antigonadotropins is to assure the cessation of vitellogenesis.

Recently, Medeiros et al. (2002, 2004) have provided evidences that eicosanoids control insect oogenesis, modulating the levels of cAMP on the ovarian follicles. In many vertebrate processes, including endocytosis, eicosanoids modulate the level of second messengers (Smith 1989). Eicosanoids receptors are coupled to changes in the intracellular levels of cAMP (Stanley-Samuelson and Pedibhotla 1996). So, events controlled by cAMP and protein phosphorylation, such as receptor recycling, vesicle fusion and vesicles recycling can be coordinated by eicosanoids (Fallon and Schwartz 1988, Griffiths and Hollinshead 1990, Colombo et al. 1994, Fallon et al. 1994, Mellman 1996, Foti et al. 1997). In $R$. prolixus, lipoxygenase products down-regulate cAMP production, thus increasing the rate of yolk uptake while cyclooxygenase products upregulate cAMP levels inhibiting yolk accumulation. In Hyalophora cecropia, it was reported that cyclic nucleotides (cAMP and cGMP) induce termination of VG uptake (Wang and Telfer 1996).

Among triatomines R. prolixus is the most studied insect with respect to VG and VT. Scarce information is available in other triatomines species such as Triatoma infestans and Triatoma protracta. The native molecular mass of VG of Triatoma protracta is $437 \mathrm{kDa}$ (Mundall and Engelmann 1977) and $220 \mathrm{kDa}$ for VG and VT of Triatoma infestans (Salomón and Stoka 1986). VT and VG of Triatoma 
infestans show partial immunological identity with VG and VT of Panstrongylus megistus and R. prolixus (Salomón and Stoka 1986).

In $R$. prolixus, VT native molecular mass is 430 and $260 \mathrm{kDa}$ (Chalaye 1979). The native particles dissociate in four subunits under denaturing conditions. The molecular mass of the subunits are $180 \mathrm{kDa}, 158 \mathrm{kDa}, 50 \mathrm{kDa}$ and $46 \mathrm{kDa}$ (Masuda and Oliveira 1985). Similar estimates for VT subunits were obtained by Valle et al. (1987). The VG of $R$. prolixus is synthesized in the fat body as a high molecular mass precursors of $205 \mathrm{kDa}$ and $190 \mathrm{kDa}$ (Valle et al. 1993). VG is secreted to the hemolymph and it is taken up by the growing oocytes at the ovary by receptor mediated endocytosis (Oliveira et al. 1986). Inside the eggs VG is referred to as VT to differentiate it from VG from the hemolymph. Despite this nomenclature, slight physical-chemical modifications occur on VG molecule during its uptake and storage, and scarce information is available for most insect groups. Upon fertilization, VT which was previously accumulated inside the oocyte during the process of oogenesis is used by the new embryo and ends up with the eclosion of the first instar nymph (Oliveira et al. 1989). Embryonic development occurs initially as an embryonic differentiation that is followed by nymphal differentiation inside the egg. During the initial phase VT is not significantly utilized. In $R$. prolixus around day 10 , when katatrepsis occurs (Huebner 1984), only $15 \%$ of the total VT are used (Oliveira et al. 1989). From this point onward, VT is rapidly used by the embryo and at day 15 the first instar nymph hatches. Around $50 \%$ of the total content of VT are still present in the gut of the new insect, which disappears in the following five days (Oliveira et al. 1989). So, possibly this strategy is used by these insects to improve their chance to survive in nature, since the first instar nymphs have approximately five days to find a new host from where they will suck blood for the first time in their lives.

It was very intriguing the fact that only $15 \%$ of total VT are used to build up a new embryo (katatrepsis). The remaining VT is utilized inside the gut of the embryo. This fact suggests that part of the VT content is used for embryonic differentiation and another part for nymph differentiation inside and outside of the egg. Looking more carefully to the characteristics of VT, it was possible to recognize and separate three different populations of VT in $R$. prolixus (Salerno et al. 2002). These populations were named VT1, VT2 and VT3 according to the order of elution in an ion exchange column. One interesting feature about them is that they seem to be segregated inside the oocyte (Salerno, unpublished data). Another interesting feature about them is that the content of phosphate varies. VT1 is the less phosphorylated population and the first to be eluted from the column (Salerno et al. 2002). This variation can eventually be explained by the presence of two enzymes present in $R$. prolixus oocytes, an acid phosphatase (Nussenzveig et al. 1992) and casein kinase II (CK II) (Silva-Neto and Oliveira 1993). Masuda and Oliveira (1985) have shown the presence of phosphate associated with protein moiety of VT, specifically at serines residue. CK II recognizes clusters of phosphorylated serine residues, so the participation of this enzyme in the modification of phosphorylation status of this protein is a good possibility. Melo et al. (2000) demonstrated in R. prolixus that epithelial cells derived from large follicles are able to synthesize ovarian VG (O-VG). O-Vg elutes at the same position of VT1, suggesting that VT1 is of different origin from other populations. Salerno (2001) demonstrated that VG, synthesized at the fat body, gives rise to the VT3 population as consequence of its post-endocytic modification. Recently, we have collected evidences that VT2 population is synthesized by trophocytes (Salerno, unpublished data). So, it looks like the different populations found inside the $R$. prolixus oocytes are the result of a concerted effort of different cells such as fat body cells, follicular cells and trophocytes. The origin of different populations may explain the differential behavior of each population in ion exchange column.

No significant differences were observed in neutral lipid composition among all different popu- 
lations of VT, but some differences in the glycosilation status of proteins were observed. The presence of glucose associated with the oligossacharide of VG purified from the hemolymph and also associated with the oligossacharide of ovarian VG suggests that VGs from fat body and ovary are secreted after their oligossacharide is processed at the Golgi apparatus. The decrease in the content of glucose of VT3 must be attributed to the post-endocytic processing of VG. Post-endocytic processing of VT has already been reported by Giorgi et al. (1993). The lack of glucose in the oligossacharide associated with VT2 can be attributed to its different origin.

It is intriguing that in some insects VG is synthesized in the fat body, in others also by follicle cells and in the case of Rhodnius also by the tropharium cells characterizing its triple origin. The timing of O-VG synthesis of $R$. prolixus resembles that of egg-specific protein of Bombyx mori (Irie and Yamashita 1983). This protein is also synthesized in follicle cells and appears in the late phase of oocyte maturation. It is tempting to speculate that $\mathrm{O}-\mathrm{Vg}$ (or VT1) of $R$. prolixus plays a similar role, as egg specific protein in Bombyx mori. In this insect, egg-specific protein is located at the outer layer of the oocyte and utilized even before VG (Irie and Yamashita 1980).

VT1 is localized at the outer layer of oocyte (Salerno, unpublished data), so this population of VT will possibly be the first one to be used by the embryo, similar to what occurs with egg-specific protein of Bombyx mori. The proportion of VT1 population from the total is around $15 \%$, approximately the amount used by the embryo up to day 10 after oviposition (Oliveira et al. 1989) when yolk is enclosed by the embryo (Kelly and Huebner 1986).

A very important feature of Rhodnius VTs is the fact that they are produced and stored inside the egg in different periods of oocyte maturation. VT2 is probably the first one to be stored inside the egg since it is synthesized by the trophocytes (Coelho and Gomes, personal communication), followed by the deposition of VT3 from the hemolymph. The last VT to be deposited is VT1 which is synthesized by follicle cells derived from large follicles (Melo et al. 2000).

\section{NON-VITELLIN YOLK PROTEINS}

As VTs can account for 60 to $90 \%$ of the protein content of the mature oocyte, other oocyte proteins have been taken out of the spotlight, independent of their being also abundant, varying from $1-20 \%$ of total proteins. Although VTs are known to serve as source of amino acids, lipids, phosphate, and carbohydrates for the growing embryo (Yamashita and Indrasith 1988), non-VT proteins carry other non-proteic components to be used by the embryo (biliverdin, carotenoids, iron, calcium, heme and an extra amount of amino acids, phosphate and lipids) as recently reviewed by Masuda et al. (2004).

\section{RHODNIUS HEME-BINDING PROTEIN (RHBP)}

It has recently been discovered that the presence of a pink pigment in the eggs of $R$. prolixus described in the work of Sir V.B. Wigglesworth (1943) as being partially degraded hemoglobin ("katahemoglobin"), is in fact a new protein (Oliveira et al. 1995) now known as Rhodnius Heme-Binding Protein (RHBP). Wigglesworth also presented data suggesting that a similar phenomenon was occurring in the cattle tick Boophilus microplus, where thousands of deepbrown colored eggs are laid after a blood meal.

The hypothesis of Wigglesworth that heme from vertebrate was being recycled by the arthropods was also adopted by O'Hagan (1974), who showed that an amount of heme equivalent to $10 \%$ of that found in the blood ingested by the tick was found in the eggs of this arachnid. However, the suggestion that the heme from the diet was being reused was not demonstrated directly and was openly in disagreement with the well-established concept that all nucleated cells make their own heme (Ponka 1997). This apparent conflict was directly investigated by Braz et al. (1999), showing Boophilus as the first multicellular organism to be unable to make its own heme. Therefore a hallmark in the adaptation of ticks to feed on blood during evolution may 
have been the acquisition of mechanisms to absorb and transport heme through the hemolymph and deliver it to cells, especially to the growing oocytes, where a huge amount of heme is accumulated during oogenesis.

We isolated and characterized the pink pigment (RHBP) from both hemolymph and oocytes of $R$. prolixus, showing that it was in fact a hemeprotein composed of a single $15-\mathrm{kDa}$ polypeptide chain. cDNA of RHBP was cloned and sequenced. The full-length RHBP cDNA codes for a pre-protein of 128 amino acids and the deduced amino acids sequence present no significant homology to any known proteins (Paiva-Silva et al. 2002). Studies of RHBP structure are under progress (Nagem et al. 2001).

The presence of apoRHBP in the hemolymph functions as an antioxidant defense to protect Rhodnius from the challenge of dealing with the excess of heme formed upon hemoglobin digestion. RHBP in the hemolymph promptly binds one heme per polypeptide chain non-covalently. The binding of heme by RHBP suppresses the generation of activated oxygen species, thus protecting the insect against oxidative stress (Dansa-Petretski et al. 1995). As mentioned above, in spite of the heme detoxification mechanisms (hemozoin formation), part of the heme, originated from the digestion of hemoglobin, crosses the gut wall (Dansa-Petretski et al. 1995), and binds to RHBP, which led to the idea that heme was being recycled in Rhodnius. The situation in Rhodnius is more complex than that of the tick, because the hemipteran has a fully active heme biosynthesis pathway (Braz et al. 1999). Hence, possibly Rhodnius synthesize its own heme but also recycles part of the heme from the digestion of host hemoglobin.

An important function of RHBP in the hemolymph is to transport heme to the heart where it is degraded to biliverdin (Paiva-Silva, unpublished data). This "unloading" of RHBP in the heart is probably important to help the insect to maintain a safe level of apo-RHBP in the hemolymph.

RHBP isolated from the oocyte is fully satu- rated with heme and cannot bind additional heme. So, it is not possible to attribute any anti-oxidant role to this protein inside the oocyte. The function of RHBP in the egg must be of a different nature from that in the hemolymph. The presence of RHBP associated with heme in the oocyte is responsible for the characteristic pink color of $R$. prolixus' oocytes.

RHBP is accumulated by growing oocytes through receptor-mediated endocytosis and is directed to the yolk granules (Machado et al. 1998). Although several organs and tissues are able to incorporate RHBP, the ovary is by far the most active site of RHBP accumulation.

Limiting the availability of heme-RHBP, but maintaining normal levels of VG and lipophorin in the hemolymph, the females of $R$. prolixus produce only a few but normal eggs. Experimental maneuvers to increase the concentration of heme-RHBP in the hemolymph resulted in an increased number of eggs produced in a dose-dependent manner (Machado et al. 1998). This is an indication that a balanced amount of heme-RHBP and other yolk proteins such as VT is required to build up the yolk granules.

VG and lipophorin do not compete with RHBP during the process of RHBP uptake, suggesting either the existence of different receptors or different binding sites for the same receptor. Recently, the presence of a lipophorin receptor has been discovered, independent of the $\mathrm{Vg}$ receptor in Aedes aegypti oocyte (Cheon et al. 2001). Independently of the mechanism used for their internalizations, it is clear that a cross information is required in order to obtain a balanced amount of RHBP and VG inside the mature egg. When RHBP is limiting, the strategy used by the female is to reduce the number of viable eggs. All attempts to induce R. prolixus females to produce eggs without heme-RHBP, using diets free of heme, failed (Machado, unpublished data).

The expression of RHBP is induced by a blood meal (Paiva-Silva et al. 2002) and is temporally correlated with the appearance in the hemolymph of other yolk proteins such as VG (Oliveira et al. 1986) and lipophorin (Gondim et al. 1989), providing the 
balanced need of VG RHBP and lipophorin for egg production. Besides that, RHBP secretion by fat bodies is also dependent on intracellular levels of heme (Paiva-Silva et al. 2002). The amount of heme originated from hemoglobin digestion is not enough to guarantee normal oogenesis in vitellogenic Rhodnius females. De novo heme biosynthesis is necessary to obtain a normal vitellogenesis. Using succynil acetone, a specific inhibitor of ALA dehydratase (Lindblad et al. 1977), a substantial decrease in the number of eggs laid is observed (Braz et al. 2001), which is reversed by feeding the insects with porphobilinogen, an intermediate downstream in the pathway.

Very recently, it has been shown that the entry of RHBP in the oocyte is controlled by eicosanoids (Medeiros et al. 2002, 2004). $\mathrm{PGE}_{2}$ (one of the products of the cyclooxygenase pathway) decreased RHBP uptake, while indomethacin (a cyclooxygenase inhibitor) increased uptake in vitro and in vivo. Upon treatment with indomethacin, two ovarian polypeptides (18 and $25 \mathrm{kDa}$ ) were dephosphorylated, suggesting that a protein phosphorylation signal transduction pathway is involved. In fact, there is a growing set of evidences relating endocytosis and cell signaling pathways (Di Fiore and De Camilli 2001).

The tight control observed between the uptake of RHBP and the other yolk proteins such as VT required to build up the yolk granules, can be explained in part by the following observations: a clear decline in RHBP content is observed during embryogenesis without reduction in heme content (Braz et al. 2002), thus suggesting that heme from RHBP is recycled. So, a minimum amount of heme, inside the egg, must be provided in order to obtain a normal development.

In several arthropods including Rhodnius, a large fraction of the yolk remains unused in the crops of first instar nymphs (Oliveira et al. 1989). In the first five days following hatching, Rhodnius nymphs completely degrade the remaining yolk proteins and a dark material can be observed in the lumen of midgut of these non-fed insects, possibly hemozoin.
Hemozoin formation can be promoted by perimicrovillar membranes of the midgut (Oliveira et al. 2000), but it can also be an autocatalytic process, dependent on the existence of pre-formed hemozoin (Dorn et al. 1995). The presence of hemozoin in the midgut of the non-fed nymphs will possibly seed the formation of more hemozoin as the result of blood digestion that will occur when the insect feeds on vertebrate blood for the first time in its life. This is also an important reason for the presence of RHBP in the eggs. Taken together, these observations demonstrate that RHBP utilization during embryogenesis can provide heme to de novo synthesis of embryo hemeproteins. Also that is a source of food for the newly hatched nymph and seeds the formation of hemozoin in the gut of the newly hatched nymph, to prepare the insect to receive its first ingestion of blood in nature. All these events are important enough for the embryo development so that the females of $R$. prolixus do not produce a single egg without RHBP in it.

\section{LIPOPHORIN}

During oogenesis in insects, oocytes accumulate a great amount of lipids, which are supplied by lipophorin, a major hemolymphatic lipoprotein (Chino et al. 1981, Kawooya and Law 1988, Sun et al. 2000, Ziegler and Ibrahim 2001). Lipophorin transports different classes of lipids, such as diacylglycerol, phospholipids, cholesterol, hydrocarbons, free fatty acids, between insect various tissues, according to physiological demand (Soulages and Wells 1994, Blacklock and Ryan 1994, Ryan and Van der Horst 2000). Hematophagous insects, such as the triatomines $R$. prolixus and Panstrongylus megistus, ingest large amounts of blood at each meal and, like it occurs in other insects, digestion causes the release of free fatty acids in midgut lumen which, after absorption, are used in the midgut epithelium for the synthesis of other lipids, as phospholipids, cholesteryl esthers, tri- and diacylglycerol (Tsuchida and Wells 1988, Turunen and Crailsheim 1996, Canavoso et al. 2004, Grillo and Gondim, 
unpublished data). Lipids are then transferred to circulating lipophorin that transports them to the organs where they are stored and/or utilized (Atella et al. 1995, Coelho et al. 1997, Canavoso et al. 2004).

In the adult females of $R$. prolixus, during the days following a blood meal, lipophorin transports phospholipids (Gondim et al. 1992) to the ovaries, and the rate of incorporation of these lipids varies according to oocyte developmental stage (Gondim et al. 1989), in the same way that it was observed for the rate of VT uptake (Oliveira et al. 1986). Considering the fact that during oogenesis a huge amount of membranes must be synthesized to cope with oocyte growth and accumulation of yolk granules (Telfer et al. 1982), phospholipids incorporated by vitellogenic oocytes are possibly used to build up these membranes. In fact, when the fate of radioactive phospholipids was followed after their transfer from lipophorin to oocytes, a great part of radioactivity was found associated with membranes of yolk bodies (Gondim 1992).

Chino et al. (1977) addressed the question of lipid accumulation in the ovaries of the silkmoth Philosamia cynthia, and concluded that there was more lipid in the oocytes than it was expected due to the present amounts of lipophorin and VT. It was proposed, then, that lipophorin delivered lipids, but was not incorporated by the ovaries.

In $R$. prolixus, oocytes store triacylglycerol (Santos and Gondim, unpublished data), possibly in lipid droplets, that will be used during embryogenesis, as discussed below. So, in triatomines, lipophorin probably delivers not only phospholipids, but also diacylglycerols to the growing oocytes, as it does in Manduca sexta, where the participation of a membrane-associated lipoprotein lipase may be involved (Van Antwerpen et al. 1998). In this moth, where lipophorin of two density classes (Beenakkers et al. 1988) can be found in adult hemolymph, HDLp (high density lipophorin) is taken up, associated lipids are removed and the lipoprotein is converted to a very-high density lipophorin (VHDLp) inside the oocytes, and stored there (Kawooya et al. 1988). However, in this same insect, most lipids are sup- plied to the ovaries by circulating LDLp (low density lipophorin), that transfers lipids to the oocytes without protein incorporation (Kawooya and Law 1988). In another lepidopteran, Hyalophora cecropia, lipophorin is also accumulated by the ovaries (Telfer et al. 1991), and in the mosquito Aedes aegypti this lipoprotein can be found in oocytes (Sun et al. 2000).

So, lipophorin may have its apoproteins incorporated or not, depending on insect species and also on the organ under analysis, and when lipophorin is not accumulated by the cells to which it delivers lipids, the particle can be reloaded, acting as a reusable lipid shuttle (Downer and Chino 1985, Van Heusden et al. 1987, Van Antwerpen et al. 1988, Kawooya and Law 1988). This is the case of the developing ovaries of $R$. prolixus, where lipophorin apoproteins are not accumulated by the oocytes (Gondim et al. 1989, Machado et al. 1996), and it was demonstrated that it can be loaded with lipids at the fat body and the midgut (Atella et al. 1992, 1995). The midgut shows a greater capacity to transfer lipids to lipophorin soon after feeding, while the fat body shows an increased rate of lipid transfer later on, when midgut is almost empty (Coelho et al. 1997).

Although lipophorin is not incorporated by the developing oocytes of $R$. prolixus, for delivering lipids it interacts with specific binding sites at cell surface. Receptors for this lipoprotein were studied in some insects, as the flight muscles and fat body of Locusta migratoria (Hayakawa 1987, Dantuma et al. 1996), the fat body and midgut of Manduca sexta (Tsuchida and Wells 1990, Gondim and Wells 2000) and the ovaries of Aedes aegypti (Cheon et al. 2001). In R. prolixus, lipophorin binding to specific sites at membranes from fat body and midgut was characterized (Pontes et al. 2002, Grillo et al. 2003), and a receptor from oocyte membrane is under investigation.

Later on, during egg development, imported lipids will propel embryo formation. The role played by these macromolecules should include fueling of metabolic process, shaping and plasticity 
of cell boundaries, as well as intracellular signaling. Despite the presumed role of lipid and lipid-derived molecules on cell development, the number of studies addressing such matter is scarce. Most of the available studies have focused on non-mammalian vertebrates' models such as chicken, lizards, alligators and turtles (Rowe et al. 1995, Speake et al. 1998, Speake and Thompson 1999, 2000). As regards insects, most studies have focused on the role played by lipophorin in lipid storage. Once the number of studies where triatomine species were employed as models is still scarce we provide here a brief account of data including a discussion of similar aspects found in other insect orders.

The first study providing an analysis on lipid dynamics during insect development was conducted by Kinsella (1966). In this study a qualitative and quantitative picture of sterol and sterol esters dynamics during Periplaneta americana egg development is depicted. Total sterol content of developing embryos is kept constant whereas the proportion of esterifed sterol increased. By the time of nymphal eclosion the total content of esterified sterol increased from 20 to $42 \%$. Also, fatty acid composition of the sterol esters is quite altered. Sterol esters isolated in early embryogenesis are appreciably more saturated due to an increase on the content of palmitic (16) and stearic (18) acids. Sterol esters isolated late on embryogenesis are more unsaturated, due to an increase on the content of oleic (18:1) and linoleic acid (18:2). The significance of such shift on fatty acid saturation is unclear and is probably linked to their metabolic function during embryogenesis. A similar shift on the composition of fatty acids associated with neutral lipids was verified by Lipsitz et al. (1969) in the cricket Acheta domesticus. During larval development the content of myristic acid on monoacylglycerols changed from $34.5 \%$ of total sterified fatty acids at day 12 to 10.9 at day 30 . Such data demonstrate that the profile fatty acid sterification is probably following punctual adjustments during either embryo/larval development. The role played by such adjustments, as well as the mechanism underlying such changes, are still unknown.
Kinsella and Smyth (1966) showed that the amount of mono- and diacylglycerols remained constant throughout egg development. However, by the time of nymphal emergence the amount of such lipids increased sharply as a consequence of triacylglycerol hydrolysis. Total extractable lipid decreased from 39.5 to $23.2 \%$ of the dry weight of the oothecae. Triacylglycerol fraction solely decreased by $75 \%$. In the blood sucking-bug $R$. prolixus a similar profile was found by our group. Triacylglycerol content decreased to half the value found in oocytes by the end of egg development period, although triacylglycerol percentage was kept constant during embryogenesis (Santos and Gondim, unpublished data). Free fatty acid (FFA) metabolism was also followed during the same period by Kinsella (1967). Data indicated a rather different profile with a surge on FFA content from $0.2 \mathrm{mg} \%$ of dry matter to $1.4 \%$ in the last day of egg development. Such result is a clear indication of triacylglycerol hydrolysis mediated by lipase activity particularly before nymph hatching. Therefore, measurements of FFA levels are a direct measure of respiratory quotient once such molecules are catabolized to provide respiratory energy for both invertebrate and vertebrate tissue (Kinsella 1967).

Dynamics of larval to pupa transition was followed by Pant et al. (1973). Total lipids and neutral lipids increased through larval development and attained the maximum concentration at fifth instar stage. After pupation there was a sudden decrease in pupal fat body lipids, which suggests their utilization on metabolism. FFA and phospholipids are also accumulated during the larval development in the insect body. Once after ecdysis a decrease on either free fatty acid or phospholipids is noticed in pupal fat body.

The above mentioned studies employed separation and quantification techniques to follow lipid dynamics during insect development. Such strategy implies in the homogenization of the whole tissue and therefore assumptions could not be made regarding the intracellular localization of such molecules. In order to fulfill this gap, Atella and Shahabuddin 
(2002) employed fluorescently labeled lipids to investigate maternal lipid uptake and distribution in mosquitoes. Such strategy demonstrated for the first time that maternal fatty acid and phospholipids segregate differently in tissues of newly hatched mosquito larvae. Inside the adult ovary lipids were found to be stored in yolk granules of developing oocytes and distributed evenly. In neonate larvae, however, maternal fatty acids are stored along the side of the body. They are located inside structures that resemble the larval fat body, especially at the base of the body hair and in the thorax, where the muscles are located. Such distribution implies a role in energy for the food intake after birth. Most maternal phospholipids are concentrated in the motile intestinal gastric cecae and are probably released into the gut lumen to act as food emulsifiers during larval feeding. Such distribution was found in Aedes aegypti and also in Anopheles gambiae suggesting that it may be a consequence of a general segregation pathway common to several mosquito species. Now, we are testing the lipid segregation in R. prolixus embryogenesis. As preliminary data show that maternal derived lipids remained in the newborn nymphs, then it is likely that a similar mechanism is taking place in $R$. prolixus (Fig. 2) (Silva-Neto, Masuda and Atella, unpublished data). Fatty acid sterification shift and the differential partitioning of lipid classes during egg development described above imply that during insect egg development a unique and complex cell biology process is taking place. The extent and uniqueness of such process should receive the attention of investigators working in the area in the future.

\section{CALCIUM-BINDING PROTEINS}

Calcium ion is involved in a variety of functions in living organisms as allosteric activator of some enzymes, modulator of cytoskeletal rearrangements, muscle contraction, hormone action, membrane fusion, transmembrane passage and also as a second messenger. So, the metabolism of calcium must be precisely regulated inside the cells in order to attend all the metabolic demands of individual cells. Thus calcium is an essential component of the egg, since it will be required during development of a new embryo. These observations led to the conclusion that this ion must be packed inside the egg during the process of oogenesis, in order to allow a normal development of the insect.

\section{Calmodulin (CAM)}

One possible way to pack calcium ion inside the oocyte is through the calcium-binding protein, calmodulin. Calmodulin $(\mathrm{CaM})$ is a ubiquitous, acidic, calcium-binding protein of $20 \mathrm{kDa}$ with fourhigh affinity $\mathrm{Ca}^{2+}$-binding sites present in eukaryotic cells. When intracellular calcium concentration rises above $1 \mu \mathrm{M}$, the binding of calcium drives a conformational change in calmodulin. The calciumbound state of calmodulin associates with a variety of proteins and modulates their activities which explain why it is involved in numerous cellular regulatory processes. In the cockroach Blatella germanica, a large amount of $\mathrm{CaM}$ is stored in growing oocytes, where it comprises $0.9 \%$ of the total solubilized protein (Zhang and Kunkel 1992). Isolation of $B$. germanica $\mathrm{CaM}$ followed by detailed molecular characterization demonstrated close similarity to vertebrate CaMs (Zhang and Kunkel 1992). Small structural differences distinguish it from all other animal CaMs. The demonstration of $\mathrm{CaM}$ synthesis by vitellogenic follicles, and its absence in the hemolymph of the female, together with the demonstration of its synthesis suggest that most of the $\mathrm{CaM}$ incorporated by the egg is of ovarian origin. It was demonstrated in Oncopeltus fasciatus that a gap junctionally transmitted epithelial cell signal was necessary for yolk uptake (Anderson and Woodruff 2001). Similar signal is also necessary in insects representing other orders suggesting that possibly this phenomenon was conserved during evolution (Wakmonski and Woodruff 2002). The epithelial cell signal, transmitted through gap junction stimulating the incorporation of yolk, is calmodulin (Brooks and Woodruff 2004). CaM possibly plays a dual function: during oogenesis and embryogenesis. 


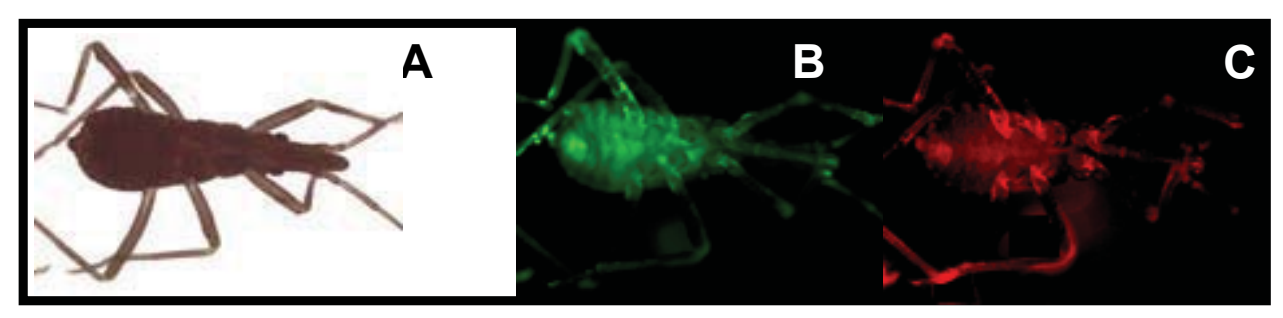

Fig. 2 - Maternal lipid localization in R. prolixus neonate nymphs. Purified lipophorin was double labeled with Texas Red PE and Bodipy FA injected into vitellogenic females; typically four days after injection, eggs were laid. They were kept at $28^{\circ} \mathrm{C}$ until hatching. Nymphs were immediately collected and kept on ice. Fluorescence associated with newborn nymph was analyzed by fluorescent microscopy. (A) Phase-contrast image. (B) Localization of Bodipy FA in newborn kissing-bug nymph. (C) Localization of Texas Red PE in newborn kissing-bug nymph.

$\mathrm{CaM}$ stored in the egg is present in the cytoplasmic compartment surrounding yolk granules and is virtually absent from yolk granules (Zhang and Kunkel 1994). The storage of a huge amount of CaM in developing eggs has in turn led to different speculations regarding its role in the programmed degradation of VT during embryogenesis. VT is able to bind $\mathrm{CaM}$ and after degradation of VT, the CaM-binding capacity is retained by the $53-\mathrm{kDa}$ fragment generated by limited proteolysis. Besides that, the amount of $\mathrm{CaM}$ in developing eggs dramatically decreases after the beginning of limited proteolysis of the yolk. Therefore, CaM can be involved with limited proteolysis of VT. The stoichiometry between VT and $\mathrm{CaM}$ is (1:1), which reinforces this possibility.

\section{Rhodnius Calcium-Binding Protein (RCBP)}

In addition to CaM, another calcium-associated protein yolk was isolated and characterized from oocyte and hemolymph from $R$. prolixus. This protein capable of binding calcium and storing it inside the oocyte (Silva-Neto et al. 1996) is a phosphoprotein. It exhibits an apparent molecular mass of $18 \mathrm{kDa}$ on gel filtration, but it migrates as an $8 \mathrm{kDa}$ band on Tris-Glycine SDS-polyacrylamide gels because of its high degree of phosphorylation. $24 \%$ of the total number of residues are serine, being phosphoserine the sole phosphorylated amino acid found. A protein that has a similar amino-terminal and resembles the oocyte form of the protein was also found in the hemolymph. Radioactive phosphopro- tein was isolated from the hemolymph and oocytes of insects fed with blood containing ${ }^{32} \mathrm{Pi}$, and it was injected into vitellogenic females. Only the ovary was able to incorporate the protein. Both radioactive phosphoproteins were detected inside the oocyte 16 hours following injection. The phosphoprotein binds $50 \mathrm{~mol}$ of ${ }^{45} \mathrm{Ca} / \mathrm{mol}$ of protein with a $\mathrm{K}_{0.5}$ of $10^{-3} \mathrm{M}$. Based on these characteristics, it was named Rhodnius calcium-binding phosphoprotein (RCBP). RCBP resembles phosvitin, one of the most phosphorylated proteins found in nature, isolated from non-mammalian vertebrates. While phosvitin is a product of the post-endocytic cleavage of VG, RCBP is not, because it is already present as such in the hemolymph. As phosvitins (28-35 kDa) are associated with yolk granules (Byrne et al. 1989) it is also possible that RCBP is involved with yolk granule formation.

The exact function of RCBP in the egg is not known, but preliminary data suggest that RCBP is used by developing embryos during the initial 10 days of post-oviposition (Silva-Neto, unpublished data) during which katatrepsis is completed and the yolk is enclosed by the embryo (Kelly and Huebner 1986). The role of RCBP is still not known, and requires further investigation.

\section{YOLK ASSOCIATED ENZYMES}

Female gamete formation in oviparous organisms occurs synchronously with another biochemical process which is yolk deposition. Huge amounts 
of carbohydrates, proteins and lipids are gradually deposited into growing oocytes during oogenesis. Such process will allow embryo development outside the maternal body. Yolk platelets are specialized organelles where yolk components are stored. Nevertheless the composition of yolk platelets has been already described in detail for many insects but the mechanisms which underlie the utilization of yolk components, by developing embryo, remain to be understood in detail. A recurrent strategy has been the identification and biochemical analysis of yolk platelet-associated enzymes. Such analysis has paved the way for our current understanding of yolk platelet physiology in $R$. prolixus.

$R$. prolixus egg development is a fertilization triggered event which occurs continuously over a period of 15 days. The major biochemical event, taking place in yolk granules, is the gradual processing of VT. Oliveira et al. (1989) showed a continuous alteration in VT molecule following oviposition. The authors divided this process into two phases: limited and extensive proteolysis. The first phase spans for 10 days as embryogenesis proceeds while the main VT bands, detected on native-PAGE gels, progressively migrate further into the gel. The second phase occurs inside the digestive system following day 10 and VT content declines to half of its initial value at hatching. The remaining material is used up by the first instar nymph during its initial five days of life outside the eggshell. In the following paragraphs we describe yolk-associated enzymes studied in our laboratory, whose role was assigned by examination of their biochemical properties during egg development.

Nussenzveig et al. (1992) were the first to describe a set of acid hydrolases associated to yolk platelet in $R$. prolixus. The presence of such enzymes was first detected incubating purified yolk platelets in different $\mathrm{pHs}$, which induced a differential profile of VT proteolysis. Protease activity towards VT was maximal at $\mathrm{pH}$ values between 3.5 and 4.5. This reaction was solely blocked by the classical cathepsin D (CD) inhibitor, pepstatin A, in a dose dependent-manner. Yolk platelets were sub- jected to freezing and thawing followed by ultracentrifugation. This strategy led to the obtainment of a pellet which contained almost all enzyme activity. It also demonstrated a close association between the protease and the membrane of the yolk platelet. Further experiments showed that $R$. prolixus $(\mathrm{CD})$ is a $45 \mathrm{kDa}$ protein whose activity towards a specific fluorescent peptide designed for aspartyl proteases increases over 15-fold during egg development (Fialho et al. 2005).

A second enzyme associated to yolk platelets was a lysosomal acid phosphatase. Such enzyme is able to hydrolyze p-nitrophenyl phosphate with a peak of activity around $\mathrm{pH}$ 5.0. This reaction is strongly blocked in the presence of sodium fluoride and tartrate but not by p-chloromercuriobenzoate (Nussenzveig et al. 1992). Later on, it was demonstrated that Rhodnius acid phosphatase (AP) activity is mediated by a single enzyme of $94 \mathrm{kDa}$ (Fialho et al. 2002). CD and AP were therefore physically associated to yolk platelet and we then hypothesized that they should play a role in VT proteolysis during egg development. Such hypothesis was investigated as follows.

Non-mated females of $R$. prolixus produce and lay non-fertilized eggs (Davey 1967). Such eggs were assayed for AP activity and the enzyme activity obtained was compared with the one from fertilized eggs homogenized in different days following oviposition (Fialho et al. 2002). AP activity is 5 -fold increased compared to oocytes in the first days following fertilization. In contrast nonfertilized but oviposited eggs showed no activation of this enzyme. This result indicated for the first time a close link between AP activity and oocyte fertilization. Once VT is a phosphorylated molecule, we followed the fate of metabolic labeled phosphoserines with the aid of radioactive inorganic phosphate in both set of eggs. Surprisingly, fertilized eggs showed a decrease of $60 \%$ of their phosphoserine content. A similar profile was not observed in non-fertilized eggs where a decrease of only $20 \%$ was detected. Such results were confirmed by the analysis of phosphoserine content with the aid of 
monoclonal antibodies raised against phosphoserine (Fialho et al. 2002). We next analyzed the ability of phosphorylated molecules to inhibit pNPPase activity catalyzed by partially purified AP. VT but not isolated phosphoserine, mannose 6-phosphate and ATP could block such reaction. This result was a clear demonstration that VT is a substrate specifically recognized by egg AP. Therefore, in $R$. prolixus egg fertilization triggers a cascade of signaling event which culminates in the dephosphorylation of VT by AP. This finding implied that removal of covalently bound phosphate groups is a part of a programmed pathway for appropriate embryo utilization of yolk reserves. Such biochemical pathway appears to be unique to $R$. prolixus, once $B$. germanica developing eggs, where the same phenomenon was investigated, do not present such alterations (Nordin et al. 1990).

Efforts from many laboratories working worldwide with developing eggs of different arthropods have provided a huge amount of information about the physical-chemical properties, amino acid and gene sequences of several proteases involved in VT degradation. Some of the mechanisms, which regulate VT proteolysis, have been described as well. These mechanisms include for instance the expression of genes coding for proteases, inactivation of protease activity by inhibitory peptides, or most commonly, $\mathrm{pH}$-induced activation of selfprocessing proteases. Proteolytic systems described in developing eggs of arthropods usually rely on the acidification of YPs. Such mechanism was demonstrated in several models such as developing eggs of Xenopus, sea urchin and tick and therefore its correlation to yolk utilization is clearly established (Fagotto 1990, 1991, Fagotto and Maxfield 1994). Furthermore, the presence of a unique acidification system in $R$. prolixus composed by an $\mathrm{H}^{+}$-PPase and also by an $\mathrm{H}^{+}$-ATPase has been recently demonstrated (Motta et al. 2004). Although these studies have shed light on a recurrent strategy for the modulation of protease activity, they do not provide any information about the susceptibility of VT molecule to the proteolytic attack.

Once VT, AP and CD share the same intracel- lular compartment, i.e. yolk platelets, we hypothesized that these enzymes might have a concerted action against VT. Fialho et al. (2005) followed the fate of yolk-associated CD activity originally described in $R$. prolixus oocytes during egg development. They have shown that CD activity, in total egg homogenates, is blocked by the classical aspartyl protease inhibitor, pepstatin A. Surprisingly, AP inhibitors such as $\mathrm{NaF}, \mathrm{Na}^{+} / \mathrm{K}^{+}$tartrate and inorganic phosphate also block VT proteolysis. This blockage is not observed when tyrosine phosphatase inhibitors such as vanadate and phenylarsine oxide or levamisole were used in VT proteolysis assay. $\mathrm{NaF}$ concentrations able to block isolated AP activity do not affect the activity of partially purified $C D$. Therefore, a specific repressor of VT proteolysis should be dephosphorylated by AP in vivo. The identity of this molecule should be addressed further. The surge of phosphoproteome techniques will allow a close look to the transient nature of phosphate groups attached to phosphoproteins during egg development in the future. Combination of such strategy with a complete survey on non-proteic phosphorylated molecules able to be dephosphorylated by AP should provide some detail on the mechanism of $\mathrm{CD}$ regulation in this system. In conclusion, the above data demonstrated for the first time that AP, besides its simple hydrolytic function of low molecular weight substrates, plays a role in the regulation of the initial steps of protein digestion inside yolk platelets.

Dephosphorylation-coupled digestion of proteic substrates is a recurrent theme in cell biology. The presence of covalently bound phosphate on VTs was soon recognized as a remarkable feature of those proteins (Allerton and Perlmann 1965). Nowadays, data concerning the physical-chemical properties, amino acid sequencing and cDNA sequences are available for VTs in different insect groups. Thus it became clear that every VT molecule from any organism contains some degree of covalently bound phosphate in its structure (Byrne et al. 1989, Sappington and Raikhel 1998). Extensive phosphorylation is particularly found in non-mammalian vertebrate VGs within a domain named phosvitin (Byrne 
et al. 1989). Nearly half of its amino acid composition is made up of serines and most of them are phosphorylated. The presence of such motif on VTs provides an anionic surface where some nonphosphorylated serines are clustered among phosphorylated serines. This region is a consensus sequence for further phosphorylation by a protein kinase named casein kinase II (CK II).

CK II is a cyclic nucleotide-independent calcium/calmodulin-insensitive protein kinase (SilvaNeto et al. 2002) strongly inhibited in vitro by heparin and which is able to utilize either ATP or GTP as phosphate donors in the phosphorylation reaction (Pinna and Meggio 1997). The naturally occurring consensus sequences of CK II on VTs make these proteins a suitable substrate for the identification of such enzyme on insect eggs. Silva-Neto and Oliveira (1993) demonstrated the presence of CK II on fully grown oocytes of $R$. prolixus. Such enzyme is 3-fold activated after oocyte fertilization and VT is its main substrate throughout the whole egg development (Fialho et al. 1999). Limited proteolysis takes place on VT molecule in the third day after ovoposition. From this point on CK II activity towards VT gradually disappears. Such result demonstrated a specific structural requirement for the recognition of Rhodnius VT by CK II (Fialho et al. 1999). Nonfertilized eggs do not display this transient CK II activation profile. This result was a strong indication that CK II modulation is also included in the programming of egg development. Isolation of such enzyme allowed a close look into the dynamic of VT phosphorylation by such enzyme (Silva-Neto et al. 2002). Incubation of purified VT with purified CK II led to the incorporation of $2 \mathrm{~mol}$ of phosphate $/ \mathrm{mol}$ VT. However, the total number of phosphorylation sites available can be altered by previous incubation of VT with alkaline phosphatase. Under such condition limited dephosphorylation increased the total number of phosphorylation sites. However, extensive dephosphorylation led to a dramatic decrease on the total phosphorylation sites. Such results led us to speculate that the presence of CK II in yolk platelets assures the high degree of VT phosphory- lation. This would allow the interaction of VT with cations at certain regions which might be important for two processes: first, to keep VT in a paracrystaline state inside the yolk platelet where its "packing" degree would require a lower number of water molecules; second, to prevent the availability of cations such as calcium from being able to trigger lipid-peroxidation catalyzed by neighboring hemeproteins in the yolk platelet such as RHBP. Such hypotheses are currently under investigation in our laboratory.

\section{EICOSANOIDS AS LOCAL REGULATORS OF OOGENESIS}

The control of insect oogenesis is associated with hormones such as juvenile hormone and ecdysone (Engelmann 1979, Kunkel and Nordin 1985). These hormones control the synthesis of yolk protein and its receptors (Raikhel and Dhadiala 1992); the patency of follicular cells (Sevala and Davey 1989, Raikhel and O'Lea 1991); and uptake of yolk proteins (Stoffolano et al. 1992). The great complexity and variety of cells that compose insect ovaries suggest the participation of local mediators that also control and coordinate oogenesis. However, local mediators which could help in the control of oogenesis are little understood.

Eicosanoids are local lipid mediators produced from the oxygenation of $\mathrm{C}_{20}$ polyunsaturated fatty acids, most notably arachidonic acid (C 20:4 $\omega-6$ ). Once released from membrane phospholipids, arachidonate can be oxygenated by prostaglandin $\mathrm{G} / \mathrm{H}$ synthase (cyclooxygenase) or (5-, 8-, 12-, 15-) lipoxygenases to form prostaglandins (PGs), leukotrienes (LTs) or related hydroxy acids, which can play a role as intra or extracellular signals (Smith 1989, Stanley 2000, Funk 2001). These compounds regulate many physiological and physiopathological processes in addition to modulating inflammatory and immunological responses in mammals (Samuelson 1983, O`Neill and Ford-Hutchinson 1993, Murdoch et al. 1993, Funk 2001, Pai et al. 2003), but their production is not restricted to these animals, as several invertebrate species have been shown to 
produce PGs and LTs (Meijer et al. 1986, StanleySamuelson et al. 1991, Petzel et al. 1993, StanleySamuelson and Pedibhotla 1996, Stanley 2000, Reddy et al. 2004).

Eicosanoids have several actions in reproductive biology of vertebrates (Murdoch et al. 1993, Priddy and Killick 1993, Funk 2001), which have encouraged many research groups to study their relevance in insect reproduction. The first report on the biosynthesis of eicosanoids in the insect reproductive system was in the house cricket Acheta domesticus by Destephano and Brady (1977). They showed that male testes and seminal vesicles were able to produce PGs, and a PG synthesizing complex was transferred from male to female via spermatophore during mating. That study also showed that PGs have had a stimulating effect on egg-laying behavior. Since then, the prostaglandin biosynthesis has been recognized in reproductive tracts of several insects as Bombyx mori (Yamaja-Setty and Ramaiah 1979), Teleogryllus commodus (Loher et al. 1981), Trichoplusia ni (Hagan and Brady 1982), Locusta migratoria (Lange 1984), Musca domestica (Wakayama et al. 1986), Triatoma infestans (Brenner and Bernasconi 1989) and R. prolixus (Medeiros et al. 2002).

However, the model of PG synthesizing complex transfer and egg laying behavior release showed to be not conserved, even among the crickets. In other models such as L. migratoria, Trichoplusi ni, Musca domestica, PG injections are not able to induce oviposition (Stanley 2000). It has also been described that there is a transfer of PGs or arachidonic acid rather than enzymes in insects such as Bombyx mori and Musca domestica during mating (Stanley-Samuelson and Pedibhotla 1996, Stanley 2000). The role of PGs in these systems remains to be elucidated, but Loher (1979) showed a net increase in the egg number in unmated Teleogryllus commodus females after $\mathrm{PGE}_{2}$ injection. Among triatomines, Medeiros et al. (2002) showed in $R$. prolixus that derivatives of cyclooxygenase pathway decrease the yolk protein uptake, suggesting that these compounds can act as regulators of oogene- sis, as seen in other arthropod models (Spaziani et al. 1993, 1995, Sagi et al. 1995).

Lipoxygenase products are described in the reproductive tract of some invertebrates, e.g. four starfish species (Meijer et al. 1986), the sea squirt Ciona intestinalis, and the surf clam Spisula solidissima (Hada et al. 1997). Pagés et al. (1986) demonstrated lipoxygenase activity in Drosophila melanogaster extracts and also the presence of lipoxygenase-like immunoreactivity in ejaculatory bulb of male flies. The reproductive tract of mated firebrat Thermobia domestica has lipoxygenase activity (Ragab et al. 1987, 1991), and the egg laying behavior is dependent of phospholipase $A_{2}$ activity, which seems to be augmented after mating (Bitsch et al. 1995). In triatomines, Medeiros et al. (2004) showed, by a pharmacological approach, that the lipoxygenase pathways products act as positive effectors of yolk uptake.

The eicosanoids signaling in vertebrate involves cyclic nucleotide modulation. The participation of second messengers involved in eicosanoid signaling in insects or even in invertebrates is scarce but there are some evidences of modulation by cyclic AMP levels in these systems. Meijer et al. (1986) showed a reduction of cAMP levels in oocytes of starfish Methasterias sp. after treatment with 8(R)HETE, which induced oocyte maturation. Sagi et al. (1995) demonstrated an increase in cAMP levels following treatment of ovarian tissue with $\mathrm{PGE}_{2}$ in the prawn Macrobrachium rosembergii. Spaziani et al. (1995) also showed, in the crayfish Procambarus paeninsulanus, a correlation among ovarian tissue contraction, $\mathrm{PGF}_{2 \alpha}$ levels and tissue cAMP levels. The role of $\mathrm{PGE}_{2}$, which was also augmented during oogenesis progression (Spaziani et al. 1993), remains to be elucidated. Medeiros et al. (2004) showed, in $R$. prolixus, that cyclooxygenase products (inhibitors of yolk uptake) increase the ovarian cAMP levels, while the lipoxygenase products (stimulators of yolk uptake) act in an opposite way decreasing the level of this second messenger (Wang and Telfer 1996). Worth mentioning is that this is the first time that products of both pathways, by co- 
ordinated manner, could be playing roles in an invertebrate reproductive system, in an autocrine and/or paracrine way, regulating the rate of yolk deposition.

The late 1980s and the 1990s saw many reports on molecular biology of genes involved with eicosanoid signaling in mammals, but this is still to be achieved in invertebrates (Stanley 2000). Thus, the insect genomes (Heckel 2003), trancriptomes and proteomes of some organs of these animals could bring light to this area, allowing a better understanding of synthesis, targeting and metabolism of eicosanoids in insect reproductive physiology.

\section{CONCLUDING REMARKS}

Although VT is the most represented protein in the majority of insect eggs studied, a classical work done by Yamashita and Irie (1980) on B. mori showed that eggs with no VG in them can produce normal insects. They demonstrated that VG or VT is not essential for egg maturation and embryonic development. Thus, other proteins can replace the function played by VT in normal egg development. In $R$. prolixus, the presence of three different populations of VT with different origins, produced at different periods of oocyte maturation, suggests that each of them may play different roles during embryogenesis. In $B$. mori, part of these roles was substituted by different proteins. Insects adapted to food sources as different as the blood of vertebrates and plants produce VGs (lipoglycophosphorylated proteins) which are stored inside their eggs. These molecules contain most, but not all, of the basic elements needed to construct an embryo, including amino acids, carbohydrates, and lipids. Non-VT yolk proteins, such as RHBP, RCBP and lipophorin of $R$. prolixus, play a specialized role. Each insect has its own particular non-VT protein, possibly complementing particular nutritional elements in function of its adaptation to a particular source of food during evolution. Among triatomines information on VT and non-VT proteins is very scarce yet and future research must include efforts on the characterization of these types of molecules in species other than $R$. prolixus. Cloning sequencing and expressing receptors for VT and non-VT yolk proteins will be crucial to understand the cellular pathway involved with the yolk granule assembly, and to give us some clues about the role performed by each of the non-VT yolk proteins during embryogenesis of triatomines.

The localization of these proteins and receptors inside the oocyte but also the characterization of the organelles to which they are associated must be subject of future research. Although yolk granules seem morphologically very similar, they are probably heterogeneous in composition and play distinct function. Insects initiate their embryonic development, after fertilization, by nuclei fusion followed by mitotic nuclear division without the corresponding cytoplasmatic division, resulting in a sincitial blastoderm. Cellularization takes place at the periphery of the egg, and the embryo initiates its development in the cortical area of the egg. Thus, the yolk granules of the cortical area may possibly be different from those found in the central core. The yolk is used gradually, during embryogenesis, supplying materials to support metabolic demands of growing embryo dictated by the genetic program of the insect. As VT can be replaced by other proteins, non-VT proteins seem to be essential for providing specific substrates, such as their associated non-protein component such as heme, calcium, iron and lipids for embryo formation.

Enzymes of maternal origin (proteases, phosphatases, kinases and proton-pump enzymes) involved with the degradation of yolk can, possibly, be differentially distributed inside the egg. Immunolocalization of enzymes and other non-VT yolk proteins along with the different populations of VT will give us a good picture about the organization of the insect egg and will help us to understand the physiology of embryo development. The common fact observed during early embryogenesis, that only part of the total content of VT is used along with some non-VT proteins, is consistent with the idea of different VT populations playing different roles during embryogenesis.

As the result of recent studies, it is becom- 
ing clear that yolk granules are not merely digestive vesicles but rather sites where a complex metabolism occurs, finely regulated in relation to both time and space. The central issue of developmental biology is the identification of a diversity of cells that were once indistinguishable from one another. With the progress in the fields of biochemistry, cell biology, and molecular biology new technologies became available to explore these developmental mechanisms. Reliable knowledge of the fate map of the embryo and of the cell lineage of single precursor cells has been achieved, in contrast to the relative lack of information on several aspects of the metabolism of maternally inherited components of insect eggs. Thus, the challenge for the next decade is to collect enough data to understand how and where these egg proteins are used up together with their non-protein components to support cell differentiation. Besides that, it is also important to understand how their degradation is controlled in pace with the genetic program of the embryo, which enables cell differentiation (early phase of embryogenesis) and embryo differentiation (late phase) inside the egg.

Finally, it is necessary to recognize that this review is a consequence of a lifetime effort by Dr. Lent who encouraged young Brazilian students and scientists to engage in the study of triatomines. We were all stimulated by reading his papers, books and notes, and also by the scientists he trained.

\section{ACKNOWLEDGMENTS}

We express our gratitude to Heloísa S. L. Coelho, Lilian S.C. Gomes, José S.L. Junior and Litiane M. Rodrigues for their excellent technical assistance; and to Dr. Tereza Marques de Oliveira Lima for the English support in the reading of the manuscript. This work was supported by Conselho Nacional de Desenvolvimento Científico e Tecnológico (CNPq), Coordenação de Aperfeiçoamento de Pessoal de Nível Superior (CAPES), Financiadora de Estudos e Projetos (Finep), Programa de Núcleo de Excelência (PRONEX), Programa de Apoio ao Desenvolvi- mento Científico e Tecnológico (PADCT) and Fundação Carlos Chagas Filho de Amparo à Pesquisa do Estado do Rio de Janeiro (FAPERJ).

\section{RESUMO}

Em triatomíneos, assim como em outros insetos, o acúmulo de vitelo é um processo no qual um tecido extraovariano, o corpo gorduroso, produz proteínas que são empacotadas no interior de um ovo. A principal proteína, sintetizada pelo corpo gorduroso, que é acumulada no interior de um ovócito, é a vitelogenina. Este processo é também conhecido por vitelogênese. Existem crescentes evidências em triatomíneos, que além do corpo gorduroso, o ovário também produz proteínas de vitelo. A forma como estas proteínas de vitelo entram nos ovócitos será aqui comentada. O vitelo é um material complexo composto por proteínas, lipídeos, carboidratos e outros compostos minoritários que são empacotados de uma maneira organizada no interior dos ovócitos. A fertilização dispara a embriogênese, um processo que culmina com o desenvolvimento do embrião. Durante a embriogênese o vitelo será utilizado para a construção de um novo indivíduo, a ninfa de primeiro estádio. O desafio para a próxima década é entender onde e como estas proteínas de vitelo são utilizadas junto com os seus componentes não protéicos, em compasso com o programa genético do embrião, que comanda a diferenciação celular (fase inicial da embriogênese) e diferenciação do embrião (fase final da embriogênese) no interior do ovo.

Palavras-chave: ovogênese, vitelogênese, embriogênese, triatomíneos, Rhodnius prolixus.

\section{REFERENCES}

Aft RL AND Mueller GC. 1983. Hemin mediated DNA strands scission. J Biol Chem 258: 12069-12072.

Allerton SE and Perlmann GE. 1965. Chemical characterization of the phosphoprotein phosvitin. J Biol Chem 240: 3892-3898.

Anderson KL and WoodrufF RI. 2001. A gap junctionally transmitted epithelial cell signal regulates endocytic yolk uptake in Oncopeltus fasciatus. Dev Biol 239: 68-78.

Atella GC and Shahabuddin M. 2002. Differential partitioning of maternal fatty acid and phospholipid in neonate mosquito larvae. J Exp Biol 205: 3623-3630. 
Atella GC, Gondim KC and Masuda H. 1992. Transfer of phospholipids from fat body to lipophorin in $R$. prolixus. Arch Insect Biochem Physiol 19: 133-144.

Atella GC, Gondim KC and Masuda H. 1995. Loading of lipophorin particles with phospholipids at the midgut of $R$. prolixus. Arch Insect Biochem Physiol 30: 337-350.

Beenakkers AMTh, Chino H and Law JH. 1988. Lipophorin Nomenclature. Insect Biochem 18: $1-2$.

Bellés X. 2004. Vitellogenesis Directed by Juvenile Hormone. In: RAIKHEL AS AND SAPPINGTON TW (Eds), Reproductive Biology of Invertebrates, vol. 12, Part B: Progress in Vitellogenesis, Science Publishers, Inc., Enfield, USA / Plymouth, UK, p. 157-198.

Bianchi AG, Coutinho M, Pereira SD, Marinotti O AND TARgA HJ. 1985. VG and VT of Musca domestica: Quantification and synthesis by fat bodies and ovaries. Insect Biochem 15: 77-84.

Bitschi C, Ragab A AND Chap H. 1995. Inhibition of phospholipase A2 modulates fecundity in the primitive insect Thermobia domestica (Thysanura). J Insect Physiol 41: 209-216.

Blacklock BJ and Ryan RO. 1994. Hemolymph lipid transport. Insect Biochem Mol Biol 24: 855-873.

Bonhag PF. 1955. Histochemical studies of the ovarian nurse cell tissues and oocytes of the milkweed bug, Oncopeltus fasciatus (Dallas). II Sudanophilia, phospholipids and cholesterol. J Morphol 97: 283311.

Bonhag PF. 1958. Ovarian structure and vitellogenesis in insects. Annu Rev Entomol 3: 137-160.

Braz GRC, Coelho HSL, Masuda H and Oliveira PL. 1999. A missing metabolic pathway in the cattle tick Boophilus microplus. Curr Biol 9: 703-706.

Braz GRC, Abreu L, Masuda H and Oliveira PL. 2001. Heme biosynthesis and oogenesis in the bloodsucking bug, Rhodnius prolixus. Insect Biochem Mol Biol 31: 359-364.

Braz GRC, Moreira MF, Masuda H and Oliveira PL. 2002. Rhodnius heme-binding protein (RHBP) is a heme source for embryonic development in the blood-sucking bug $R$. prolixus. Insect Biochem Mol Biol 32: 709-717.
Brenner RR and Bernasconi A. 1989. Prostaglandin biosynthesis in the gonads of the hematophagous insect Triatoma infestans. Comp Biochem Physiol 93B: $1-4$.

Brooks RA AND WoodrufF RI. 2004. Calmodulin transmitted through gap junctions stimulates endocytic incorporation of yolk precursors in insect oocytes. Dev Biol 271: 339-349.

BRoOKES VJ. 1969. The induction of yolk protein synthesis in the fat body of an insect Leucophea maderae by an analog of the juvenile hormone. Dev Biol 20: 459-471.

BRUnT A. 1971. The histology of the first batch of eggs and their associated tissue in the ovariole of Dysdercus fasciatus (Heteroptera: Pyrrhocoridae) as seen with the light microscope. J Morphol 134: 105-130.

BunING J. 1981. Cluster formation in telotrophic meroistic ovarioles. IX Congr Int Soc Dev Biol Basle (Abstract)

Byrne BM, Gruber M AND AB GB. 1989. The evolution of egg yolk proteins. Prog Biophys Mol Biol 53: 33-69.

Canavoso Le, Frede S and Rubiolo ER. 2004. Metabolic pathways for dietary lipids in the midgut of hematophagous Panstrongylus megistus (Hemiptera: Reduviidae). Insect Biochem Mol Biol 34: 845-854.

Chalaye D. 1979. Étude immunochimique des proteins hémolymphatiques et ovocytaires de $R$. prolixus (Stal). Can J Zool 57: 329-336.

Cheon HM, Seo SJ, Sun J, Sappington TW and RAIKHEL AS. 2001. Molecular characterization of the VLDL receptor homolog mediating binding of lipophorin in oocyte of the mosquito Aedes aegypti. Insect Biochem Mol Biol 31: 753-760.

Chino H, Downer RGH and Takahashi K. 1977. The role of diacylglycerol-carrying lipoprotein I in lipid transport during insect vitellogenesis. Biochim Biophys Acta 487: 508-516.

Chino H, Downer RGH, Wyatt GR and Gilbert LI. 1981. Lipophorin, a major class of lipoprotein of insect haemolymph. Insect Biochem 11: 491.

Coelho HSL, Atella GC, Moreira MF, Gondim KC AND Masuda H. 1997. Lipophorin density variation during oogenesis in R. prolixus. Arch Insect Biochem Physiol 35: 301-313. 
Coles GC. 1965. Haemolymph proteins and yolk formation in $R$. prolixus (Stal). J Exp Biol 43: 425-431.

Colombo MI, Mayorga LS, Nishimoto I, Ross EM AND STAHL P. 1994. GS regulation of endosome fusion suggests a role for signal transduction pathway in endocytosis. J Biol Chem 269: 14919-14923.

Couchman J And KIng PE. 1979. Germarial structure and oogenesis in Brevicoryne brassicae (L) (Hemiptera:Aphiidae). Int J Insect Morphol Embryol 8: $1-10$.

Dansa-Petretski M, Ribeiro JMC, Atella GC, MaSUDA H AND OLIVEIRA PL. 1995. Antioxidant role of $R$. prolixus heme-binding protein. J Biol Chem 270: 10893-10896.

Dantuma NP, Van MarrewiJk WJA, Wynue HJ AND VAN DER HORST DJ. 1996. Interaction of an insect lipoprotein with its binding site at the fat body. $\mathrm{J}$ Lipid Res 37: 1345-1355.

Davey KG. 1967. Some consequences of copulation in Rhodnius prolixus. J Insect Physiol 13: 1629-1636.

DAVEY KG. 1981. Hormonal control of VG uptake in $R$. prolixus Stal. Am Zool 21: 701-705.

DAveY KG. 1987. Inputs to the hormonal control of egg development in R. prolixus. Mem Inst Oswaldo Cruz 82: 103-108.

DAVIS NT. 1956. The morphology and functional anatomy of the male and female reproductive systems in Cimex lecularius L (Heteroptera; Cimicidae). Ann Entomol Soc Am 49: 466-493.

Destephano DB and Brady VE. 1977. Prostaglandin and prostaglandin synthetase in the cricket Acheta domesticus. J Insect Physiol 23: 905-911.

Di Fiore PP and De Camilli P. 2001. Endocytosis and signaling: An inseparable partnership. Cell 106: 1-4.

Dorn A, Stoffel R, Matile H, Bubendof A and RiDLEY R. 1995. Malarial haemozoin beta-haematin supports haem polymerization in the absence of protein. Nature 374: 269-271.

Downer RGH AND Chino H. 1985. Turnover of protein and diacylglycerol components of lipophorin in insect haemolymph. Insect Biochem 15: 627-630.

Engelmann F. 1970. The Physiology of Insect Reproduction. Oxford, New York: Pergamon Press.

Engelmann F. 1979. Insect VG: Identification biosynthesis, and role in vitellogenesis. Adv Insect Physiol 14: 49-109.
ENGELMANN F. 1990. Hormonal control of arthropod reproduction: Progress in comparative endocrinology. Prog Clin Biol Res 342: 357-364.

Fagotto F. 1990. Yolk degradation in tick eggs: II. Evidence that catepsin L-like proteinase is stored as a latent, acid-activable proenzyme. Arch Insect Biochem Physiol 14: 237-252.

Fagotto F. 1991. Yolk degradation in tick eggs: III. Developmentally regulated acidification of the yolk spheres. Develop Growth and Differ 33: 57-66.

Fagotto F and Maxfield FR. 1994. Changes in yolk platelet $\mathrm{pH}$ during Xenopus laevis development correlate with yolk utilization. A quantitative confocal microscopy study. J Cell Science 107: 3325-3337.

FALlON RJ AND Schwartz AL. 1988. Asialoglycoprotein receptor phosphorylation and receptor-mediated endocitosis in hepatoma cells. J Biol Chem 263: 13159-13166.

FAllon RJ, Danaher M, Saylors RL and Saxena A. 1994. Defective asialoglycoprotein receptor endocytosis mediated by tyrosine kinase inhibitors. J Biol Chem 269: 11011-11017.

Fialho E, Masuda H and Silva-Neto MAC. 1999. Protein phosphorylation during Rhodnius prolixus embryogenesis: protein kinase casein kinase II activity. Insect Biochem Mol Biol 29: 215-223.

Fialho E, Silveira AB, Masuda H and Silva-Neto MAC. 2002. Oocyte fertilization triggers acid phosphatase activity during Rhodnius prolixus embryogenesis. Insect Biochem Mol Biol 32: 871-880.

Fialho E, Nakamura A, Juliano A, Masuda H And Silva-Neto MAC. 2005. Cathepsin D-mediated yolk protein degradation is blocked by acid phosphatase inhibitors. Arch Biochem Biophys 46: 246-253.

Foti M, Carpentier JL, Aiken C, Trono D, LeW DP AND KRAuse KH. 1997. Second messenger regulation of receptors association with clathrin coated pits: a novel and selective mechanism in the control of CD4 endocytosis. Mol Biol Cell 8: 1377-1389.

Friend WG, Choy CTH and Cartwright E. 1965. The effect of nutrient intake on the development and egg production of $R$. prolixus (Stal) (Hemiptera reduviidae). Can J Zool 43 : 892-903.

FunK CD. 2001. Prostaglandins and leukotrienes: Advances in eicosanoid biology. Science 294: 18711875. 
Garcia ES and Azambuja P. 1985. A protein diet initiates oogenesis in R. prolixus. J Med Biol Res 18: 195-199.

Garcia MLM, Mello RP and Garcia ES. 1979. Ecdysone, juvenile hormone and oogenesis in $R$. prolixus. J Insect Physiol 25: 695-700.

Giorgi F, Masetti M, Ignacchiti V, Cecchettini A AND BRAdLEy JT. 1993. Post-endocytic VT processing in ovarian follicles of the stick insect Carausius morosus (Br.). Arch Insect Biochem Physiol 24: 93111.

Gondim KC. 1992. Transporte de fosfolipídeos pela lipoforina de $R$. prolixus e seu papel na ovogênese. $\mathrm{PhD}$ thesis presented to Instituto de Biofísica Carlos Chagas Filho, Universidade Federal do Rio de Janeiro, RJ, Brasil.

Gondim KC And Wells MA. 2000. Characterization of lipophorin binding to the midgut of larval Manduca sexta. Insect Biochem Mol Biol 30: 405-413.

Gondim KC, Oliveira PL and Masuda H. 1989. Lipophorin and oogenesis in R. prolixus: Transfer of phospholipids. J Insect Physiol 35: 19-27.

Gondim KC, Atella GC, Kawooya JJK and Masuda H. 1992. Role of phospholipids in the lipophorin particles of $R$. prolixus. Arch Insect Biochem Physiol 20: 303-314.

Griffiths G and Hollinshead R. 1990. Ultrastructural localization of the regulatory (RII) subunit of cyclic AMP-dependent protein kinase to subcellular compartments active in endocytosis and recycling of membrane receptor. J Cell Sci 96: 691-703.

GRILlo LAM, PonTES EG AND Gondim KC. 2003. Lipophorin interaction with the midgut of $R$. prolixus: characterization and changes in binding capacity. Insect Biochem Mol Biol 33: 429-438.

Hada T, Swift LL and Brash AR. 1997. Discovery of 5R-lipoxygenase activity in oocytes of the surf clam, Spisula solidissima. Biochim et Biophys Acta 1346: 109-119.

Hagan DV ANd BRAdy UE. 1982. Prostaglandins in the cabbage looper, Trichoplusia ni. J Insect Physiol 28: 761-765.

Hagedorn HH and Kunkel JG. 1979. VG and VT in insects. Ann Rev Entomol 24: 475-505.

Harnish D, Wyatt G and White B. 1982. Insect VTs- identification of primary products of translation. J Exp Zool 220: 11-19.

Hayakawa Y. 1987. Characterization of lipophorin receptor in locust flight muscles. Biochim Biophys Acta 919: 58-63.

HeCKel D. 2003. Genomics in pure and applied entomology. Annu Rev of Entomol 48: 235-260.

Huebner E. 1984. The Ultrastructure and Development of the Telotrophic Ovary. In: KING RC AND AKAI H (Eds), Insect Ultrastructure, vol. 2, New York: Plenum Press, p. 13-48.

Huebner E And Anderson E. 1972. A cytological study of the ovary of $R$. prolixus. I. The ontogeny of follicular epithelium. J Morphol 136: 459-493.

IRIE K AND Yamashita O. 1980. Changes in VT and other yolk proteins during embryonic development in the silkworm, Bombyx mori. J Insect Physiol 26: 811-817.

IRIE K AND Yamashita O. 1983. Egg-specific protein in the silkworm, Bombyx mori: purification, properties, localization and titre changes during oogenesis and embryogenesis. Insect Biochem 13: 71-80.

KawoOya JK AND Law JH. 1988. Role of lipophorin in lipid transport to the insect egg. J Biol Chem 263: 8748-8753.

KawoOya JK, Osir EO AND Law JH. 1988. Uptake of the major hemolymph lipoprotein and its transformation in the insect egg. J Biol Chem 25: 8740-8747.

Kelly GM And Huebner E. 1986. The effect of insect growth regulator fenoxycarb on $R$. prolixus (Insecta, Hemiptera) embryogenesis. Can J Zool 64: 2425-2429.

KINSELLA JE. 1966. Sterol metabolism during embryogenesis of Periplaneta Americana (L). J Insect Physiol 12: 435-438.

KINSELla JE. 1967. Free fatty acid metabolism during embryogenesis of Periplaneta Americana (L). Nature 14: 211-212.

Kinsella JE and Smyth JR T. 1996. Lipid metabolism of Periplaneta Americana L. during embryogenesis. Comp Biochem Physiol 17: 237-244.

KunKel JG AND Nordin JH. 1985. Yolk proteins. In: Kerkut GA And Gilbert LI (Eds), Comprehensive Insect Physiology, Biochemistry, and Pharmacology, vol. 1, Oxford, UK: Pergamon Press, p. 83-111. 
LANGE AB. 1984. The transfer of prostaglandin synthesizing activity during mating in Locusta migratoria. Insect Biochem 14: 551-56.

LeHANE MJ. 1991. The importance of blood-sucking insects. In: sc Biology of Blood-Sucking Insects. UK: Harper Collins Academics, p. 1-5.

Lima Gomes JEP, Azambuja P ANd Garcia ES. 1990. Comparative studies on the growth and reproductive performances of $R$. prolixus reared on different blood sources. Mem Inst Oswaldo Cruz 85: 299-304.

LindBlad B, Lindstedt S And Steen G. 1977. On the enzymic defects in hereditary tyrosemia. Proc Natl Acad Sci 74: 4641-4645.

Lipsitz EY, McFarlane JE and Henneberry GO. 1969. Developmental changes in the fatty acid composition of the larval lipid of the house cricket Acheta domesticus (L.). Can J Biochem 48: 264-268.

LOHER W. 1979. The influence of prostaglandin E2 on oviposition in Teleogryllus commodus. Entomol Exp Appl 25: 107-109.

Loher W, Ganjan I, Kubo I, Stanley-Samuelson DW AND TOBE SS. 1981. Prostaglandins: their role in egg laying of the cricket Teleogryllus commodus. Proc Natl Acad Sci 78: 7835-7838.

Machado EA, Atella GC, Gondim KC, Souza W and Masuda H. 1996. Characterization and immunocytochemical localization of lipophorin binding sites in the oocytes of $R$. prolixus. Arch Insect Biochem Physiol 31: 185-196.

Machado EA, Oliveira PL, Moreira MF, Souza W ANd Masuda H. 1998. Uptake of Rhodnius HemeBinding Protein (RHBP) by the ovary of $R$. prolixus. Arch Insect Biochem Physiol 39: 133-143.

Masner P. 1968. The inductors of differentiation of prefollicular tissue and the follicular epithelium in ovarioles of Pyrrhocoris apterus. J Embryol Exp Morphol 20: $1-13$.

Masuda H and Oliveira PL. 1985. Characterization of VT and VG from $R$. prolixus. Identification of phosphorylated compounds in the molecule. Insect Biochem 15: 543-550.

Masuda H, Braz GRC, Paiva-Silva GO, Silva-Neto MAC and OliveIRa PL. 2004. Non-VT Yolk Proteins. In: RAIKHEL AS AND SAPPINGTON TW (Eds), Reproductive Biology of Invertebrates, vol. 12, Part
B: Progress in Vitellogenesis, Science Publishers, Inc., Enfield, USA/Plymouth, UK, p. 289-314.

Medeiros MN, Oliveira DMP, Paiva-Silva GO, SilvaNeto MAC, Romero A, Bozza M, Masuda H AND Machado EA. 2002. The role of eicosanoids on Rhodnius heme-binding protein (RHBP) endocytosis by $R$. prolixus ovaries. Insect Biochem Mol Biol 32: 537-545.

Medeiros Mn, Mendonça LH, Hunter AL, PaivaSilva GO, Mello FG, Henze IP, Masuda H, MayaMonteiro CM and Machado EA. 2004. The Role of Lipoxygenase Products on the Endocytosis of Yolk Proteins in Insects: Participation of cAMP. Arch Insect Biochem Physiol 55: 178-187.

Meijer L, Brash AR, Bryant RW, NG K, MacLouf J AND SPRECHER H. 1986. Stereospecific induction of starfish oocyte maturation by (8R)-Hydroxyeicosatetraenoic acid. J Biol Chem 261: 17040-17047.

Mellman I. 1996. Endocytosis and molecular sorting. Ann Rev Cell Biol 12: 575-625.

Melo ACA, Valle D, Machado EA, Salerno AP, Paiva-Silva GO, Cunha-e-Silva NL, Souza W ANd Masuda H. 2000. Synthesis of VG by the follicle cells of $R$. prolixus. Insect Biochem Mol Biol 30: 549-557.

Motta LS, Silva WS, Oliveira DMP, Souza W AND Machado EA. 2004. A new model for proton pumping in animal cells; the role of pyrophosphate. Insect Biochem Mol Biol 34: 19-27.

Mundall E and Engelmann F. 1977. Endocrine control of VG synthesis and vitellogenesis in Triatoma protracta. J Insect Physiol 23: 825-836.

Murdoch WJ, Hansen TR And McPherson LA. 1993. A review - role of eicosanoids in vertebrate ovulation. Prostaglandins 46: 85-115.

Nagem RAP, Brandẽo Neto JR, Forrer VP, Meneghini R, Paiva-Silva GO, Oliveira Pl, Masuda H AND Polikarpov I. 2001. Crystallization and preliminary X-ray study of heme binding protein from the blood-sucking insect $R$. prolixus. Acta Crystallogr D 57: 860-861.

Nordin JH, Beaudoin EL and Liu XD. 1990. Proteolytic processing of Blattella germanica VT during early embryo development. Arch Insect Biochem Physiol 15: 119-135. 
Nussenzveig RH, Oliveira PL And Masuda H. 1992. Identification of yolk platelet-associated hydrolases in the oocytes of $R$. prolixus. Arch Insect Biochem Physiol 21: 252-262.

O'Hagan JE. 1974. Boophilus microplus: Digestion of hemoglobins by the engorged female tick. Expl Parasitol 35: 110-118.

O’NeILl GP AND Ford-Hutchinson AW. 1993. Expression of mRNA for cyclooxygenase-1 and cyclooxygenase-2 in human tissues. FEBS Lett 330: 156-160.

Oliveira MF, Silva JR, Dansa-Petretski M, De Souza W, Braga CMS, Masuda H and Oliveira PL. 2000. Haemozoin formation in the midgut of the blood-sucking insect $R$. prolixus. FEBS Lett 477 : 95-98.

Oliveira MO, Silva JR, Dansa-Petretski M, De Souza W, Lins U, Braga CS, Masuda H AND OliveIRA PL. 1999. Haem detoxification by an insect. Nature 400: 517-518.

Oliveira PL, Gondim KC, Guedes DS and Masuda H. 1986. Uptake of yolk protein in R. prolixus. J Insect Physiol 12: 859-866.

Oliveira PL, Petretski MDA and Masuda H. 1989. VT processing and degradation during embryogenesis in R. prolixus. Insect Biochem 19: 489-498.

Oliveira PL et al. 1995. A heme-binding protein from hemolymph and oocytes of the blood-sucking insect, R. prolixus. J Biol Chem 270: 10897-10901.

Paes MC AND Oliveira PL. 1999. An extracellular gluthatione peroxidase from the blood-sucking bug, R. prolixus. Arch Insect Biochem Physiol 41: 171-177.

Paes MC, Borges OM and Oliveira PL. 2001. Hydrogen peroxide detoxification in the midgut of the blood-sucking insect $R$. prolixus. Arch Insect Biochem Physiol 48: 63-71.

Pagés M, Roselló J, Casas J, Gelpí E, Gualde N AND Rigauld M. 1986. Cyclooxygenase and lipoxygenase-like activity in Drosophila melanogaster. Prostaglandins 32: 729-740.

Pai R, Nakamura T, Moon WS and Tarnawski AS. 2003. Prostaglandins promote colon cancer cell invasion; signaling by cross-talk between two distinct growth factor receptors. FASEB J 17: 1640-1647.

Paiva-Silva GO ET AL. 2002. On the biosynthesis of $R$. prolixus heme-binding protein. Insect Biochem Mol Biol 32: 1533-1541.
Pan ML, Bell WJ and Telfer WH. 1969. Vitellogenic blood protein synthesis by insect fat body. Science 165: 393-394.

Pant R, Nautiyal GC and Singh JB. 1973. Variation in major lipid components during development of Philosamia ricini Indian. J Biochem Biophys 10: 116-118.

Petzel DH, Parrish AK, Ogg CL, Witters NA, Howard RW AND STANLEY-SAMUELSON DW. 1993. Arachidonic acid and prostaglandin E2 in Malpighian tubules of female yellow fever mosquitoes. Insect Biochem Mol Biol 23: 431-437.

Pinna LA and Meggio F. 1997. Protein kinase CK2 (“casein kinase-2") and its implication in cell division and proliferation. Progr in Cell Cycle Res 3: 77-97.

PonkA P. 1997. Tissue-specific regulation of iron metabolism and heme synthesis: Distinct control mechanisms in erythroid cells. Blood 89: 1-25.

Pontes EG, GRILlo LM And Gondim KC. 2002. Characterization of lipophorin binding to the fat body of $R$. prolixus. Insect Biochem Mol Biol 32: 1409-1417.

Postlethwait JH AND GioRgi F. 1985. Vitellogenesis in insects. In: Browder LW (Ed), Developmental Biology, a Comprehensive Synthesis, New York: Plenum Press, p. 85-136.

Postlethwait JH, Bownes M and Jowett T. 1980. Sexual phenotype and VG synthesis in Drosophila melanogaster. Dev Biol 79: 379-387.

Pratt GE and Davey KG. 1972a. The corpus allatum and oogenesis in R. prolixus (Stal) The effect of mating. J Exp Biol 56: 223-237.

Pratt GE and Davey KG. 1972b. The corpus allatum and oogenesis in R. prolixus (Stal) I the effects of allatectomy. J Exp Biol 56: 201-214.

PRIDDY AR AND Killick SR. 1993. Eicosanoids and ovulation. Prostaglandins Leukot Essent Fatty Acids 49: 827-831.

Ragab A, Bitsch C, Thomas JMF, Bitsch J AND CHAP H. 1987. Lipoxygenase conversion of arachidonic acid in males and inseminated females of the firebrat Thermobia domestica (Thysanura). Insect Biochem 17: 863-870.

Ragab A, Durand J, Bitsch C, Chap H and Rigaud M. 1991.The lipoxygenase pathway of Arachidonic acid metabolism in reproductive tissues of the firebrat, 
Thermobia domestica, (Thysanura). Insect Biochem 21: 321-326.

RaIKHEl AS AND Dhadiala TS. 1992. Accumulation of yolk proteins in insect oocytes. Annu Rev Entomol 37: 217-251.

RAIKHEl AS AND O'Lea AO. 1991. Control of follicular epithelium development and vitellin envelope formation in the mosquito: role of juvenile hormone and 20-hydroxyecdysone. Tissue and Cell 23: 577-591.

Raikhel AS, Dhadiala TS, Cho WL, Hays AR AND Koller CN. 1990. Biosynthesis and endocytosis of yolk proteins in the mosquito. In: HAGEDORN $\mathrm{HH}$ (Ed), Molecular Insect Science, New York: Plenum Press, p. 147-154.

Reddy PS, RedDy PR and Nagaraju GP. 2004. The synthesis and effects of prostaglandins on the ovary of the crab Oziotelphusa senex senex. Gen Comp Endocr 135: 35-41.

Roth TF AND PorTer KR. 1964. Yolk protein uptake in the oocyte of the mosquito Aedes aegypti. J Cell Biol 20: $313-332$.

Roth TF, Cutting JA and Atlas JB. 1976. Protein transport and selective membrane mechanism. J Supramol Struct 4: 527-548.

Rousset A, Bitsch C And Bitsch J. 1988. Polypeptide composition and biosynthesis of the yolk proteins in the firebrat Thermobia domestica (Insecta, Thysanura). Arch Insect Biochem Physiol 9: 299-312.

Rowe JW, Holy L, Ballinger RE and StanleySAMUELSON D. 1995. Lipid provisioning of turtle eggs and hatchings: total lipid, phospholipids, triacylglycerol and triacylglycerol fatty acids. Comp Biochem Physiol B 112: 323-330.

RYAN RO AND VAN DER HORST DJ. 2000. Lipid transport biochemistry and its role in energy production. Annu Rev Entomol 45: 233-260.

Sagi A, Silkowsky J, Fleisher-Berkovish S, Danon A And Chayoth R. 1995. Prostaglandin E2 in the previtellogenic ovaries of the prawn Macrobrachium rosembergii: synthesis and effect on the level of cAMP. Gen Comp Endocr 100: 308-313.

SAlERNO AP. 2001. Origem e processamento das populações de vitelina de $R$. prolixus: comparação com vitelogenina. $\mathrm{PhD}$ thesis - Universidade Federal do Rio de Janeiro, RJ, Brasil.
Salerno AP, Dansa-Petretski M, Silva-Neto MAC, Coelho HSL and Masuda H. 2002. $R$. prolixus VT is composed of three different populations: Comparison with VG. Insect Biochem Mol Biol 32: 709-717.

SAlomón OD and Stoka A. 1986. VT and VG characterization of Triatoma infestans and related species. Acta Physiol Pharmacol Latinoam 36: 419-429.

SAMUELSON B. 1983. Leukotrienes: mediators of immediate hypersensitivity reactions and inflammation. Science 220: 279-281.

Sappington TW and Raikhel AS. 1998. Molecular characteristics of insect vitellogenins and vitellogenin receptors. Insect Biochem Mol Biol 28: 277-300.

SCHREINER B. 1977. Vitellogenesis in the milkweed bug Oncopeltus fasciatus: A light and electron microscopic investigation. J Morphol 155: 81-110.

Sevala VL and Davey KG. 1989. Action of juvenile hormone on follicle cells of Rhodnius prolixus: evidence for a novel regulatory mechanism involving protein kinase C. Experientia 45: 355-356.

Silva-Neto MAC and Oliveira PL. 1993. Protein Phosphorylation in the Oocytes of $R$. prolixus - Identification of a Type II Casein Kinase. Insect Biochem Mol Biol 23: 815-823.

Silva-Neto MaC, Atella GC, Fialho E, Paes MC, Zingali RB, Petretski JH, Ales EW and Masuda H. 1996. Isolation of a calcium-binding phosphoprotein from the oocytes and hemolymph of the blood-sucking insect $R$. prolixus. J Biol Chem 271: 30227-30232.

Silva-Neto MaC, Fialho E, Paes MC, Oliveira PL And Masuda H. 2002. Cyclic nucleotide-independent phosphorylation of VT by casein kinase II purified from $R$. prolixus oocytes. Insect Biochem Mol Biol 32: 847-857.

Sмiтh A. 1990. Transport of tetrapyrroles: Mechanisms and biological and regulatory consequences. In: Dailey HA (Ed.), Biosynthesis of Heme and Chlorophylls, New York: McGraw-Hill Publishing Company, p. 435-490.

SмIтH WI. 1989. The eicosanoids and their biochemical mechanism of action. Biochem J 259: 315-324.

SNigiRevsKaya ES AND RaIKHEl AS. 2004. ReceptorMediated Endocytosis of Yolk Proteins in Insect Oocytes. In: RAIKHEl AS AND SAPPINGTON TW (Eds), Reproductive Biology of Invertebrates, vol. 
12, Part B: Progress in Vitellogenesis, Enfield, USA/ Plymouth, UK: Science Publishers, Inc., p. 199-228.

Soulages JL AND Wells MA. 1994. Lipophorin: the structure of an insect lipoprotein and its role in lipid transport in insects. Adv Protein Chem 45: 371-415.

Souza AVG, Petretski JH, Demasi M, Bechara E and OlIVEIRA PL. 1997. Urate protects a blood-sucking insect against hemin-induced oxidative stress. Free Radical Bio Med 22: 209-214.

SpaZiani EP, Hinsch GW and EdWARdS SC. 1993. Changes in prostaglandin E2 and F2 $\alpha$ during vitellogenesis in the Florida crayfish Procambarus paeninsulanus. J Comp Physiol B 163: 541-545.

Spaziani EP, Hinsch GW and Edwards SC. 1995. The effect of prostaglandin E2 and Prostaglandin F2 $\alpha$ on ovarian tissue in the Florida crayfish Procambarus paeninsulanus. Prostaglandins 50:189-200.

Speake BK AND Thompson MB. 1999. Comparative aspects of yolk lipid utilization in birds and reptiles. Poult Avian Biol Rev 10: 181-211.

Speake BK AND Thompson MB. 2000. Lipids of the eggs and neonates of ovoviviparous lizards. Comp Biochem Physiol A 127: 453-467.

Speake BK, Murray AM and Noble RC. 1998. Transport and transformations in birds and reptiles. Prog Lipid Res 37: 1-32.

Stanley DW. 2000. Eicosanoids in invertebrate signal transduction systems. In: EICOSANOIDS IN THE REPRODUCTIVE BIOLOGY OF INVERTEBRATES. Princeton: Princeton University Press, p. 55-108.

Stanley-Samuelson DW and Pedibhotla VK. 1996. What can we learn from prostaglandin and related eicosanois in insects? Insect Biochem Mol Biol 26: 223-234.

Stanley-Samuelson DW, Gensen E, Nickerson KW, Tiebl K, Ogg CL and Howard RW. 1991. Insect immune response to bacterial infection is mediated by eicosanoids. Proc Natl Acad Sci USA 88: 1064 1068.

Stoffolano JG, Li NF, Zou BX and Yin CM. 1992. Vitellogenin uptake, not synthesis is dependent on juvenile hormone in adult of Phormia regina. J Insect Physiol 38: 839-845.

Sun J, Hiraoka T, DitTmer NT, Cho K And Raikhel AS. 2000. Lipophorin as a yolk protein precursor in the mosquito, Aedes aegypti. Insect Biochem Mol Biol 30: 1161-1171.

Telfer WH. 1954. Immunological studies of insect metamorphosis: II. The role of a sex-limited blood protein in the egg formation by the Cecropia silkworm. J Gen Physiol 37: 539-558.

Telfer WH. 1960. The selective accumulation of blood proteins by the oocytes of saturniid moths. Biol Bull 118: 338-351.

Telfer WH. 1961. The route of entry and localization of blood proteins in the oocytes of saturniid moths. $\mathrm{J}$ Biophys Biochem Cytol 9: 747-59.

Telfer WH, Huebner E AND Smith DS. 1982. The cell biology of vitellogenic follicles in Hyalophora and Rhodnius. In: KING RC AND AKAI H (Eds), Insect Ultrastructure, vol. 1, New York: Plenum Press, p. 118-149.

Telfer WH, Pan M and Law JH. 1991. Lipophorin in developing adults of Hyalophora cecropia: Support of yolk formation and preparation for flight. Insect Biochem 21: 653-663.

Tsuchida K And Wells MA. 1988. Digestion, absorption, transport and storage of fat during the last larval stadium of Manduca sexta. Changes in the role of lipophorin in the delivery of dietary lipid to the fat body. Insect Biochem 18: 263-268.

TsuchidA K AND Wells MA. 1990. Isolation and characterization of a lipoprotein receptor from the fat body of an insect, Manduca sexta. J Biol Chem 265: 5761-5767.

Tufail M, Raikhel AS and Takeda M. 2004. Biosynthesis and Processing of Insect VGs. In: RAIKHEL AS AND SAPPINGTON TW (Eds), Reproductive Biology of Invertebrates, vol. 12, Part B: Progress in Vitellogenesis, Enfield, USA/Plymouth, UK: Science Publishers, Inc., p. 1-32.

Turunen S AND Crailsheim K. 1996. Lipid and sugar absorption. In: LeHANE MJ AND BILlingsLey PF (Eds), Biology of the Insect Midgut, London: Chapman \& Hall, p. 293-320.

Valle D, Lima Gomes JeP, Goldenberg S and Garcia ES. 1987. R. prolixus vitellogenesis: dependence upon the blood source. J Insect Physiol 33: 249 254.

Valle D, Garcia ES and Goldenberg S. 1992. Influence of the blood meal source on vitellogenin synthe- 
sis by isolated fat bodies of Rhodnius prolixus. Insect Biochem Mol Biol 22: 159-166.

Valle D, Kun J, Linns J, Garcia ES and Goldenberg S. 1993. R. prolixus VG is synthesized as high molecular weight precursors. Isolation of a VG cDNA clone. Insect Biochem Mol Biol 23: 457-465.

VAN ANTWERPEN R, LINNEMANS WAM, VAN DER HORST DJ AND BEENAKers AMTH. 1988. Immunocytochemical localization of lipophorins in the flight muscles of the migratory locust (Locusta migratoria) at rest and during flight. Cell Tissue Res 252: 661-668.

van Antwerpen R, Salvador K, Tolman K and GenTRY C. 1998. Uptake of lipids by developing oocytes of the hawkmoth Manduca sexta. The possible role of lipoprotein lipase. Insect Biochem Mol Biol 28: 399-408.

van Heusden MC, van der Horst DJ, Voshol J and BEENAKKERS AMTH. 1987. Recycling of protein component of the flight-specific lipophorin in Locusta migratoria. Insect Biochem 17: 771-776.

VINCENT SH. 1989. Oxidative effects of heme and porphyrins on proteins and lipids. Seminars in Hematology 26: 105-113.

Vincent SH, Grady RW, Snider JM and MullerEBERHARD U. 1988. The influence of heme-binding proteins in heme-catalyzed oxidations. Arch Biochem Biophys 265: 539-550.

Wakayama EJ, Dillwith JW and BlomQuist GJ. 1986. Occurrence and metabolism of prostaglandins in the housefly, Musca domestica (L.). Insect Biochem 16: 895-902.

WAKMONSKI SL AND WoOdRUFF RI. 2002. For uptake of yolk precursors, epithelial cell oocyte gap junctional communication is required by insects representing six different orders. J Insect Physiol 48: 667-675.
Wang Y AND Telfer WH. 1996. Cyclic nucleotideinduced temination of VG uptake by Hyalophora cecropia follicles. Insect Biochem Mol Biol 26: 85-94.

Wigglesworth VB. 1936. The function of corpus allatum in the growth and reproduction of $R$. prolixus (Hemiptera). Q J Microsc Sci 79: 91-121.

Wigglesworth VB. 1943. The fate of the hemoglobin in $R$. prolixus and other blood-sucking arthropods. Proc Roy Soc (London) Ser B 131: 313-339.

YAmajA-Setty BN AND RAmaiah TR. 1979. Isolation and identification of prostaglandins from the reproductive organs of male silkmoth, Bombyx mori L. Insect Biochem 9: 613-617.

YAMASHITA O AND INDRASITH LS. 1988. Metabolic fates of yolk proteins during embryogenesis in arthropods. Develop Growth and Differ 30: 347-359.

Yamashita O AND IRIE K. 1980. Larval hatching from VG-deficient eggs developed in male hosts of the silkworm. Nature 283: 385-386.

Zhang Y And Kunkel JG. 1992. High abundance calmodulin from Blatella germanica eggs binds to VT subunits but disappears during VT utilization. Insect Biochem Mol Biol 22: 293-304.

Zhang Y And KunKel JG. 1994. Most egg calmodulin is a follicle cell contribution to the cytoplasm of Blatella germanica oocyte. Dev Biol 161: 513-521.

Zhu J, Indrasith LS AND Yamashita O. 1986. Characterization of VT, egg-specific protein and $30 \mathrm{kDa}$ protein from Bombyx eggs, and their fates during oogenesis and embryogenesis. Biochim Biophys Acta 882: 427-436.

ZIEGLER R AND IBRAHIM MM. 2001. Formation of lipid reserves in fat body and eggs of the yellow fever mosquito, Aedes aegypti. J Insect Physiol 47: 623-627. 